\title{
Yoncaaltı Cami ve Medresesi'nin Mimari Özelliklerinin İncelenmesi
}

\author{
Nimet ÖZTANK ${ }^{1}$
}

\section{Öz}

Mimari yapılar genellikle ait oldukları dönemin mimarlık ve sanat anlayışı ile sosyokültürel ve ekonomik özelliklerini yansıtır. Osmanlı İmparatorluğunda şehirlerinin gelişmesinde önemli rol oynayan cami, mescit ve medrese gibi yapılar bu özellikleri yansıtan önemli eserlerdir. Yeni mahalleler kurulurken genellikle, önce cami, mescit, medrese, çarşı, han, hamam vs. binaları yapılmış, bunların çevresine de konutlar inşa edilmiştir. Anıtsal ve sivil mimari örnekleri olan bu binalar bugün varlığını sürdürmeyen uygarlıkların bilgisini, sanatını, yapım sistemlerini, yapı malzemelerini ve olanaklarını yansıtan somut örneklerdir. Bu örneklerden biri de, Afyonkarahisar şehir merkezinde yer alan ve Geç Dönem Osmanlı Mimari özelliklerini taşıyan Yoncaaltı Cami ve Medresesi'dir (1910). Bu çalışmada, Yoncaaltı Cami ve Medresesi'nin mimari özellikleri, yapım sistemi ve kullanılan yapı malzemeleri hakkında bilgiler sunulmuştur. Çalışma, arşivlerden derlenen belgeler, çizimler, eski fotoğraflar, vb. ışığında yapıdaki değişimlerin izini sürerek özgün mimari ve yapısal öğeleri ortaya koymayı amaçlamaktadır. Bulgular, yapının döneminin özelliklerini cephe düzenlemesinde, harim ve medrese sofasının iç mekân tasarımında yerel ustalarca gerçekleştirildiğini göstermektedir. Elde edilen verilerin, mimari mirasımızda önemli bir yeri olan bu yapının korunabilmesi için ileride yapılacak planlama ve düzenleme çalışmalarına katkıda bulunabileceği düşünülmektedir.

Anahtar Kelimeler: Afyonkarahisar, Geç Dönem Osmanlı Mimarisi, Yapım, Doğal Taş, Volta Döşeme

\section{An Investigation of the Architectural Features of Yoncaaltı Mosque and Madrasa}

\begin{abstract}
\footnotetext{
${ }^{1}$ İstanbul Kent Üniversitesi, Sanat ve Tasarım Fakültesi, İç Mimarlık Bölümü, İstanbul

*Iligili yazar/Corresponding author: nimetoztank@hotmail.com

Generally, the buildings reflect the architectural and artistic understanding of their period and their socio-cultural and economic characteristics. In the Ottoman Empire, mosques and masjids have played an important role in the development of cities. Generally, while new neighborhoods have established in the city, mosques, masjids, madrasas, covered bazaar, khans, and baths were built first. Then dwellings were built around these buildings. These buildings are an important element of Ottoman cultural heritage and show the level of science, art, architecture, construction, and they reflect the socio-cultural, economic, and physical values in which they have been built. One of these examples is the Yoncaaltı Mosque and Madrasa (1910), located in the city center of Afyonkarahisar, with the late Ottoman Architecture features. The study aims to reveal the original architectural and construction elements of the building by tracing the changes in the structure according to documents, reports, drawings, and photographs received from archives. The results of the study show that the facades, and also in the entrance, harim, and madrasa hall were used late period Ottoman Architecture elements. It is expected that the data obtained may contribute to future planning and 
arrangement studies in order to preserve Yoncaaltı Mosque and Madrasa, which has an important place in our architectural heritage.

Keywords: Afyonkarahisar, Late Ottoman Architecture Features, Construction Technology, Natural Stone, Jack Arch

\section{Giriş}

Camiler yapıldıkları ilk zamanlardan bu yana namaz kılınan ibadethaneler olmakla kalmamış, sosyal hayatta kullanılan en önemli kamusal mekânlardan biri olmuştur. Camilerin biçimlenmesinde; yapım dönemi, iklim, topografya, kültür, sosyal özellikler, yapım sistemi ve malzemeler gibi faktörlerden biri veya bir kaçı etkili olmuştur. Osmanlı İmparatorluğu'nda şehirlerin gelişmesinde camiler önemli rol oynamış, yeni mahalleler kurulurken genellikle, önce cami, mescit, medrese, han, hamam vs. binaları yapılmış, bunların çevresine de konutlar inşa edilmiştir. Cami ve mescitlerin isimleri aynı zamanda mahallenin de ismi olmuştur. Mahalleyi oluşturan bu binalar sahip oldukları sosyo-ekonomik, kültürel ve fiziksel değerler ile kültürel mirasımızın önemli unsurlarıdır. Anıtsal ve sivil mimari örnekleri olan cami gibi binalar bugün varlığını sürdüremeyen uygarlıkların bilgisini, sanatını, yapım sistemleri ve yapı malzemeleri ve olanakları ile birlikte çeşitli bilgileri yansıtan somut örneklerdir. Bu örneklerden biri de Afyonkarahisar şehir merkezinde yer alan ve kent kimliği için önemli bir tarihi belge niteliğe sahip Yoncaaltı Cami ve Medresesi'dir (1910).

1904'de bağımsız bir sancak olan Afyonkarahisar'da at pazarı, ot pazarı ve yonca altı pazarları olmak üzere 3 ana ticari merkezi bulunuyordu. Yapı, yonca altı pazarının olduğu ticari merkezde inşa edilmiştir. Buraya "Dene Pazarı"da (Resim 1) denilmektedir (Akar, s. 55). Yoncaaltı Cami ve Medresesi Yunan işgali zamanında tahribata uğramıştır. Savaş sonrasında tamir ve bakımı yapılmış, vakıf dükkânları işletilmiştir. Vakıf dükkanları bugün de ticari işlevini sürdürmektedir.

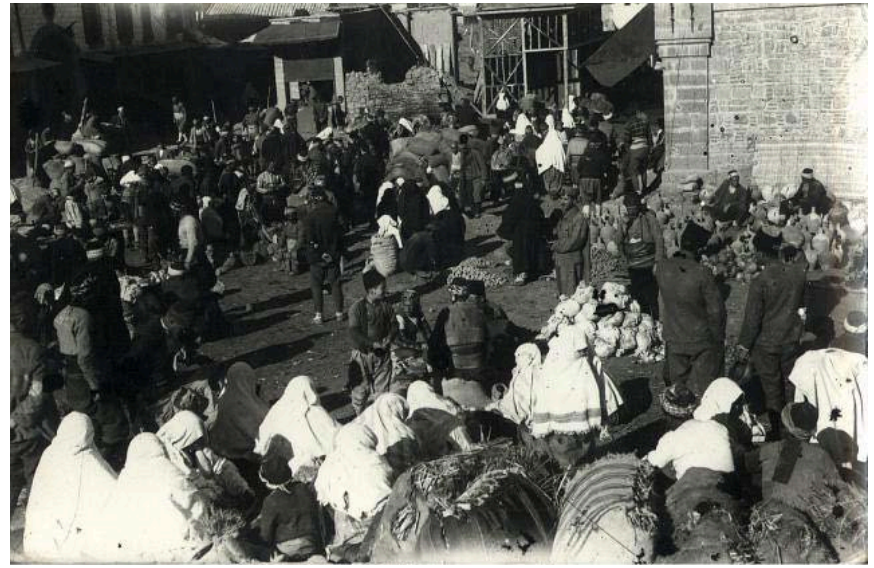

a-1910 yıllar (URL-1).

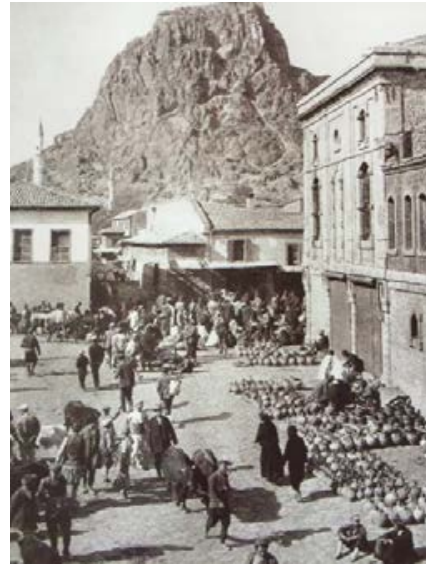

b-1930-1935 (Özpınar, 2014, s. 57).

Resim 1: Yoncaaltı Cami ve çevresindeki pazar yeri

Anıtsal yapılar bakımından şehrin önemli tarihi yapılarından olan Yoncaaltı Cami ve Medresesi'nin yakın çevresinde pek çok tarihi cami, mescit, han, türbe, hamam, çeşme bulunmaktadır; Kadı Hamamı, Otpazarı Cami, Bedesten, Gedik Ahmet Paşa Cami, Taş Medrese, Sahipler Sultan Türbesi, bunlardan bazılarıdır (Resim 2).

Yapıyı doğrudan konu edinmiş çalışmanın olmaması, mimarlık ve kent tarihi bağlamındaki öneminin yeterince ortaya konmasını sağlayamamıştır. Yapı ilgili çalışmalar incelendiğinde, Afyonkarahisar'daki tarihi eserler ve camilere ait genel 
araştırmalar içersinde yer aldığı görülmektedir. Bu eserlerde Yoncaaltı Cami ile ilgili vakfiye çalışmaları yapılmış, mimari özellikler yüzeysel anlatılmıştır. Cami ile aynı katta bitişik yapılan medrese ve ticari olarak kullanılan zemin kata ait bilgiler yetersizdir. Ayrıca bu çalışmaların aynı kaynaklardan alıntılar yaptıkları, aynı bilgileri tekrar ettikleri dolayısıyla da farklı yazarlar ve kaynaklarda benzer bilgilerin yer aldığı görülmektedir. Afyonkarahisar Vakıf Eserleri (Karazeybek, vd. 2005, s. 241-247), Anadolu'nun Kilidi Afyon (Afyon Valiliği, 2004), Tarihi ve Günümüz Afyonkarahisar Camileri (Topbaş, vd. 2007, s. 214-218) yapıya değinen çalışmalardan bazılarıdır.

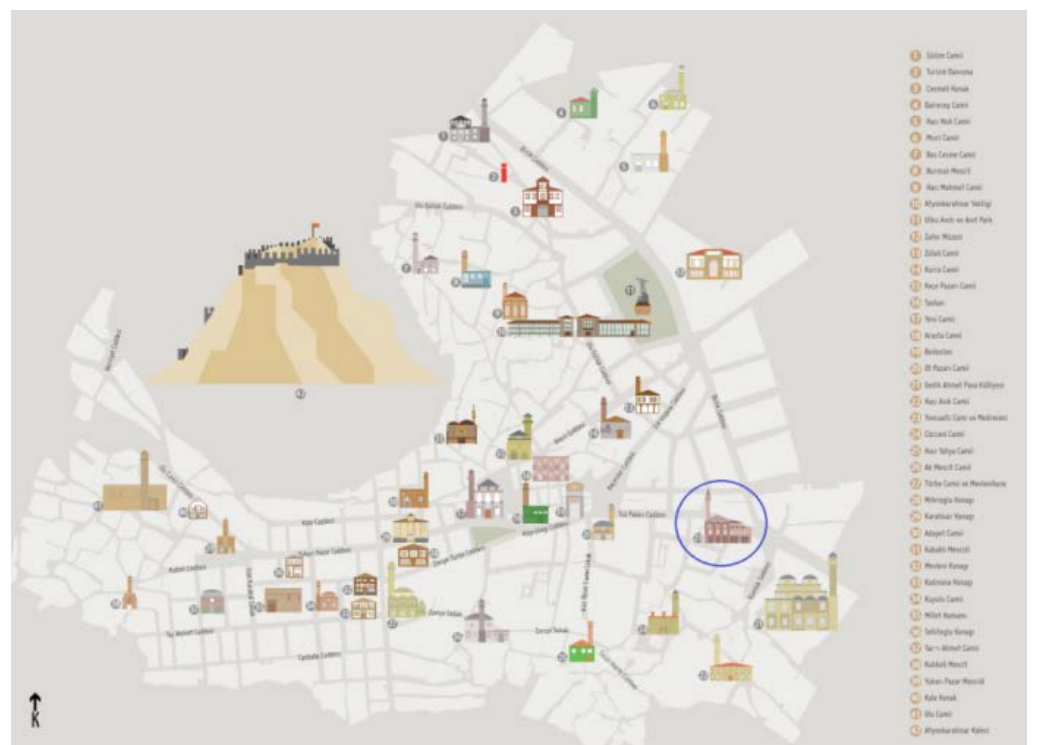

Resim 2: Yoncaaltı Cami ve Medresesi yakın çevresi yerleşim alanı (URL-2)

\section{Yapının Konumu ve Tarihçesi}

Fakipaşa Mahallesi, Tuz Pazarı Caddesi 445 Ada 66 Paftada yer alan yapı ilk olarak, 1840 yılında Süleymanoğlu Hacı Ahmet Ağa tarafından iki katlı olarak inşa edilmiştir. Vakfiyesi 11 Eylül 1840 tarihlidir (VGMA-1). Yapı, 1846, 1884 tarihli vakıf kayıtlarında Tevfikiye adıyla anılmaktadır (VGMA-2). 1909 yılında kentte meydana gelen büyük yangında harap olan yapı, aslına uygun yeniden inşa edilmiştir (Karazeybek vd., 2005, s.241). Boğa Ahmetzâde diye anılan Hacı Ahmet Efendi 18 Eylül 1912 tarihli vakfiyesinde Yoncaaltı Cami ve Medresesi'ni yeniden yaptırdığını, cami altındaki 10 adet dükkan ve mağazasını vakfettiğini belirtmektedir (VGMA-2-3). Vakfiyede ayrıca, buraların gelirinden, cami ve dükkanların bakımı ile tamirlerinin yapılması, imam, müezzin, cüzhan, mütevelli vs.nin alacakları ücretler ile görevleri belirtilmektedir (VGMA-4). Mimarı belli olmayan yapının 1910 tarihli kitabesi şöyledir (Toptaş vd. 2007, S.215):

1328 Maşallah 1326 (M. 1910)

Boğzade Hacı Ahmet Efendi sahbül hayrat, o rütbe-i hayra sai'idir ki eyle sarfı makdarad

Teavundur anın şa'nı ve/ev cüz'i ve/ev küllü

Eğer olsa, mesacid medrese muhtac-ı tamirat

Vere maksüdunu dareyne Mevla-yı bihem ta

Temelden bu mu'alia ca'ya verdi zibüi ten virat

Huzurullah'a bunda saf u saf oldukça müminler

Uruç eyler icabet-gaha tesbihatu tekhirat

'Miiferrrah ' lafzıdır tarih-i inşası anın Vehbi

Salâ ey müslimin elyak değil mi vech-i tabrat 
Zemin kat buğday loncası (Karazeybek vd., 2005, s.242), üst kat cami ve medrese olarak planlanan yapı Fevkani cami örneklerine benzemektedir. Osmanlı mimarisinde klasik dönemde görmeye başladığımız fevkani kuruluştaki camiler özellikle Geç Dönem Osmanlı mimarisinde daha yoğun bir şekilde karşımıza çıkmaktadır. Anadolu'da fevkani kuruluşta inşa edilmiş bazı camilerin alt katlarının farklı işlevler için tasarlandıkları bilinmektedir. (Polat, 2011, s. 145). Osmanlı mimarisinde genellikle cami ve medreselerin ayrı binalar olarak düzenlendiği görülür. Medrese binasının cami ile aynı kütle içerisinde yapıldığı cami örnekleri daha az sayıdadır. Osmanlı mimarisinde medreseyle aynı binada inşa edilmiş en önemli yapı Bursa'daki Hüdevendigar Camii medresesidir. Ancak bu yapıda medrese caminin üst katında yer alır (Aslanapa, 1986, s. 13). Geç Dönem Osmanlı camilerinden İzmir Salepçioğlu Camii'nde ise mektep ile kütüphane odalarına sahip medrese caminin alt katında yer alır. Yoncaaltı Cami'nde medresenin harim ile aynı katta ve bitişik planlaması, diğer örneklerden farklı kılmaktadır.

Yoncaaltı Cami'nde zamana bağlı yıpranmaların giderilmesi amacıyla çeşitli tarihlerde onarımlar gerçekleştirilmiştir (VGMA, 2013-2019): 1966 yılında iç mekanlarda onarım yapılmış, 1969 yılında çatı kiremitleri ve yağmur oluklarında yenilemeler yapılarak medrese cepheleri ve caminin kuzey yüzündeki köşe, ayak ve pencere sövelerinde bulunan kesme taşlar arasındaki duvarlar serpme sıva ile sıvanmıştır. 1985 tarihinde çatı ve iç mekanı harap durumda olan medrese bölümü onarılmıştır. 2006 yılında zemin kat dükkanların önünde bulunan ve görüntü kirliliği oluşturan saçaklar kaldırılarak yerine hareketli bez tenteler yapılmış, yapı etrafındaki manav ve zeytinciler kaldırılarak yapının görünür hale gelmesi sağlanmıştır. 2012 yılında yapının güney tarafına yer altı otoparkı ve çevre düzenlemesi yapılmıştır. Son olarak 2015-2017 arasında kapsamlı restorasyon çalışmaları gerçekleştirilmiştir (V.Kütahya B.M. arşivi, 2019).

\subsection{Yapının Mimari Özellikleri}

Yapıyı benzerlerinden farklı kılan ve Geç Dönem Osmanlı mimarisi içerisinde ona marjinal bir nitelik kazandıran en önemli unsur, -plan kurgu bakımından- cami ve medresenin birleştirilmiş planlamasıdır. Seçmeci bir anlayışla tasarlanan yapı, dönemin mimari özelliklerini taşımaktadır. Geç Dönem Osmanlı Camilerinde, 18.yy'dan itibaren Osmanlı mimarisini etkilemeye başlayan barok, ardından rokoko ve ampir üslupları ile eklektik üslubun birlikte karışıp kaynaşarak oluşturdukları kompozisyonlardan meydana gelen süslemeler yer alır (Polat, 2011, s. 175). Bu dönemin karakteristik özellikleri ilk olarak İstanbul ve çevresinde, sonrasında Anadolu'da yayıldığını görülür. Anadolu'da inşa edilen dini yapılar, İstanbul'daki örnekler kadar ustaca olmasa da, yerel ustalarca yapılan, kendine özgü bir yaklaşım ortaya koymaktadır. Bu örneklerden biri olan, Yoncaaltı Cami, bulunduğu ticaret alanının ihtiyaçları, verdiği hizmetler, hitap ettiği insan kitlesi gibi özellikler düşünülerek Fevkani olarak planlanmıştır. Yapının zemin katının bir bölümü, ilk yapıldığında bu bölgeye ticarete gelen buğday loncasının buğday koyabileceği ve atlarını bağlayabileceği mekanlara ayrılmış bir bölümü dükkan olarak inşa edilmiştir. Sonraki yıllarda ise, bu işlevini yitiren bölümlerde dükkanlara dönüştürülmüştür (Resim 3).

Yapının birinci katı cami ve medrese olarak planlanmıştır. Plan düzleminde giriş, medrese, son cemaat mekanı ve cami tek yapı olarak görülmektedir. Ancak, üçüncü boyutta farklı yükseklikler, farklı çatı çözümleri ve farklı cephe kurguları tasarlanarak mekanlar farklılaştırımıştır. Bu tasarımda, form-fonksiyon farklılaşmasının kütleye ve cephelere yansıtılması olarak düşünülebilir. 


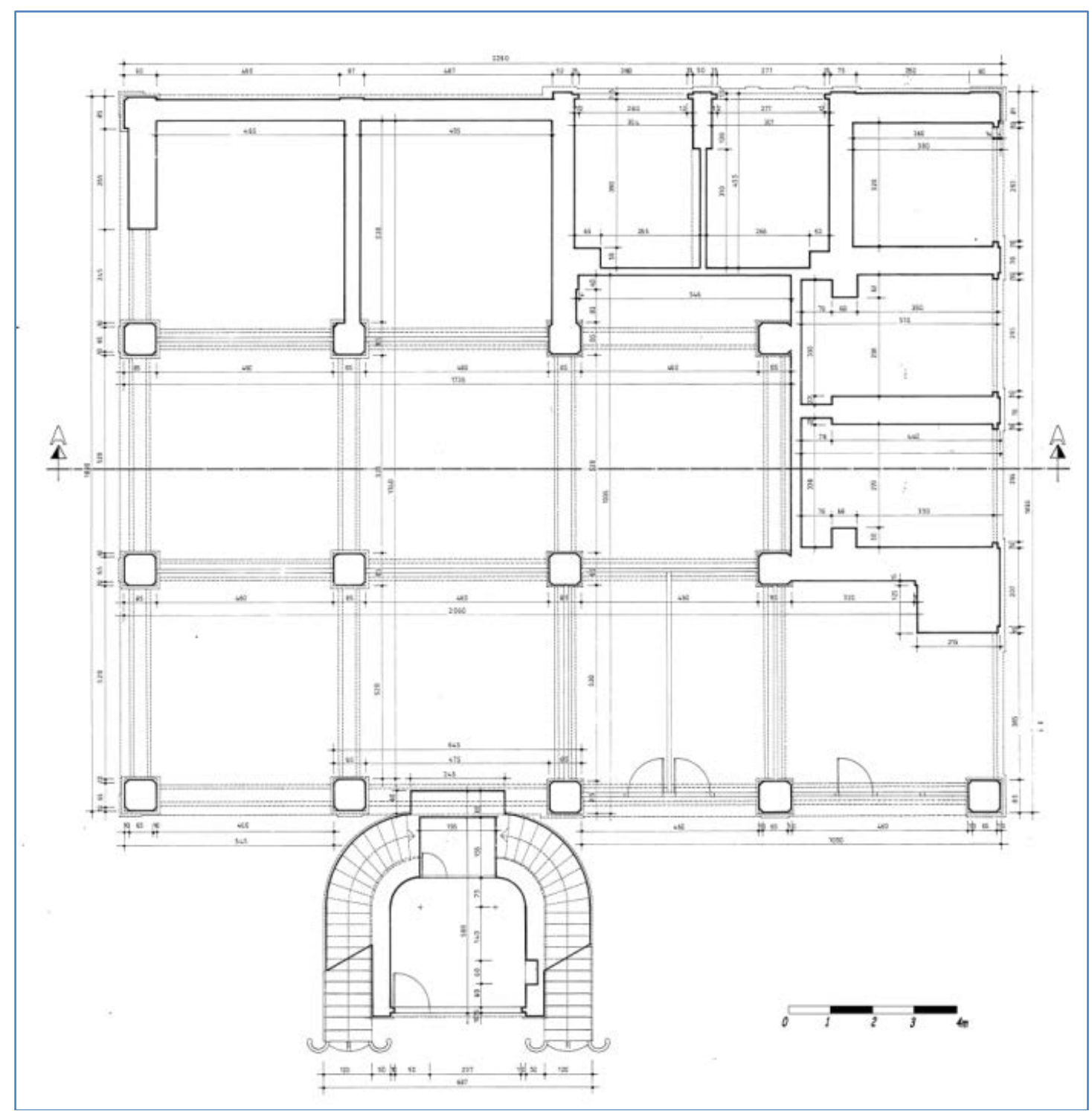

Resim 3: Yapının zemin kat planı (VGM arşivi).

\subsubsection{Cami Bölümü}

Cami, kuzeyde yer alan son cemaat yeri ile birlikte kuzey-güney doğrultuda dikdörtgen plâna sahiptir. (Resim 4-5). Cami ve medresenin ortak giriş terasına, Tuzpazarı caddesinde bulunan çift kollu, 23 taş basamaklı merdivenle çıkılır. İki yandan kıvrımlı merdivenle üst kata ulaşım Geç Dönem Osmanlı camilerinde yaygın görülen bir uygulamadır; İzmir'deki Geç Dönem Osmanlı camilerinden, Salepçioğlu Camii'nde avluya çıkış merdivenleri ve Eşrefpaşa Cami'inde son cemaat yerine giriş merdivenleri (Polat, 2011, s.147) gibi. Caminin merdiven kolları arasındaki boşluk ( $330 \times 340 \mathrm{~cm})$ zemin katta dükkan olarak planlanmıştır. Merdivenler, andezit kaplamalı $\sim 340$ x $400 \mathrm{~cm}$ boyutunda sahanlığa (taşlığa) açılır. 1935-1940 tarihli Ö.Fevzi Atabek arşivine ait fotoğraf değerlendirildiği sahanlığın ahşap karkas strüktüre sahip kapalı bir mekan olduğu görülmektedir (Resim 6). Kapalı bu mekanın ne zaman kaldırılarak bugünkü durumuna getirildiğine dair bilgiye ulaşılamamıştır. Sahanlık ve merdivenlerde metal korkuluklar kullanılmıştır (Resim 7a). 


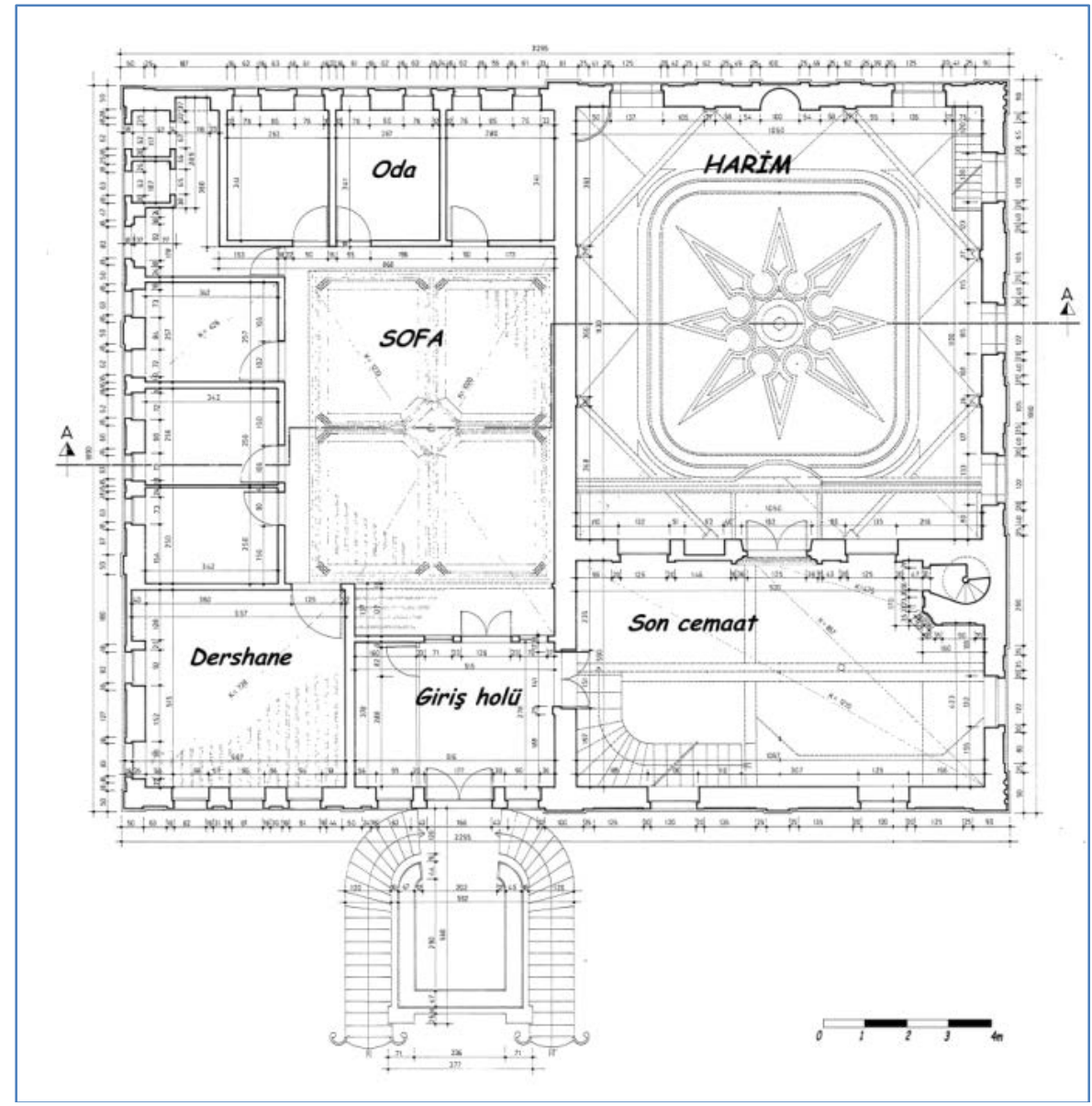

Resim 4: Yapının 1.Kat planı (VGM arşivi).

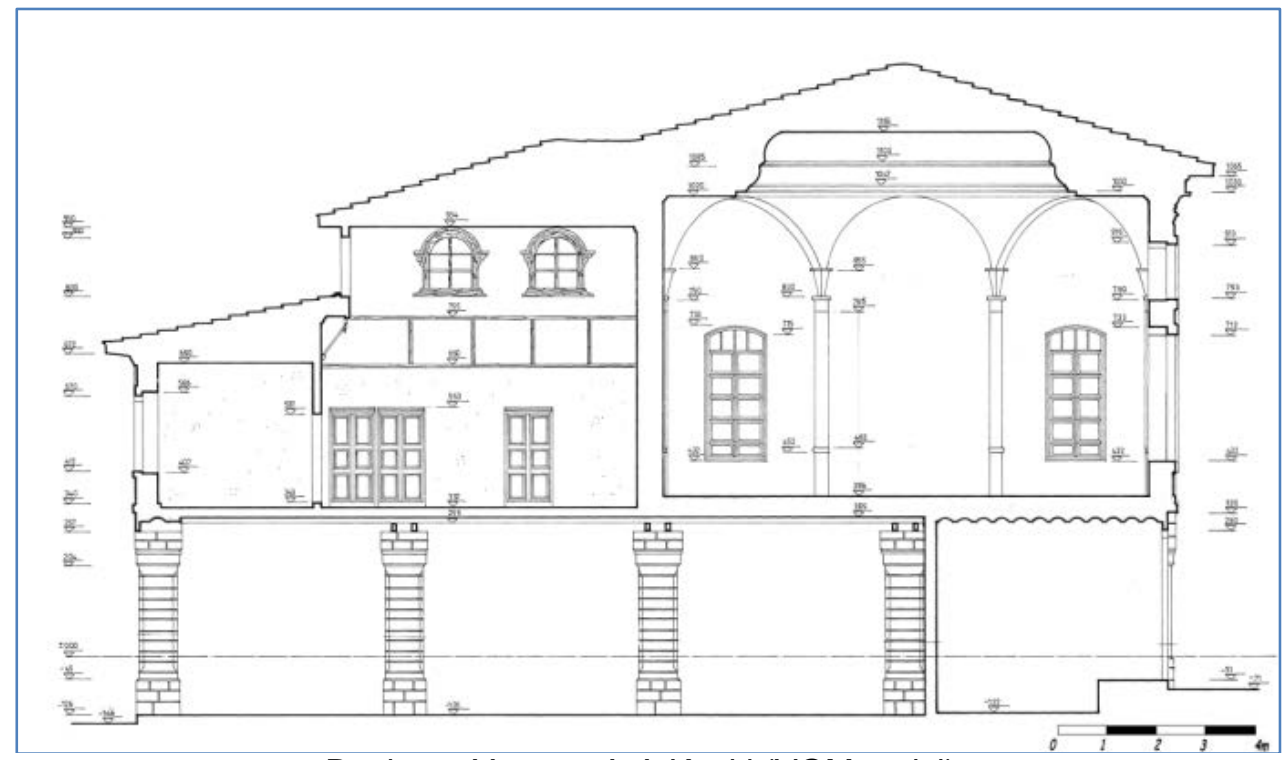

Resim 5: Yapının A-A Kesiti (VGM arşivi)

Sahanlıktan ana giriş (cümle kapısı) kapısı ile medrese ve caminin ortak giriş holüne geçilir. Ana giriş kapısı, kesme taştan oluşturulmuş basık kemer içinde çift kanat ahşap kapıdır. Bu kapının her iki yanında birer pencere bulunmaktadır. Basık taş kemerli bu pencereler, $\sim 20 \mathrm{~cm}$. genişliğindeki taş sövelerle çerçevelenmiştir. Taş sövelerin etrafındaki duvarda tuğla örgüsü ve harç kalınlıkları görülmektedir (Resim 7b). 


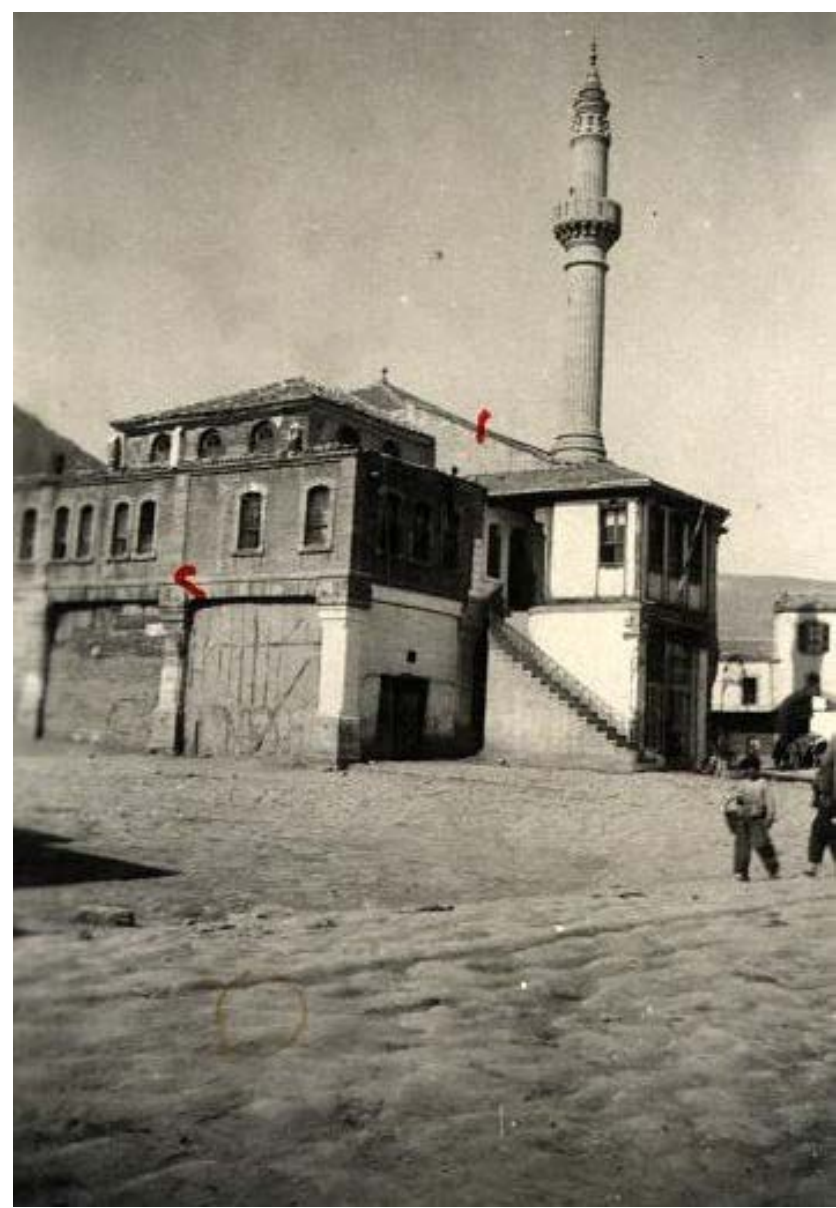

Resim 6: Yoncaaltı Cami ve Medresesi 1935-1940 (Özpınar, 2014, s. 57).

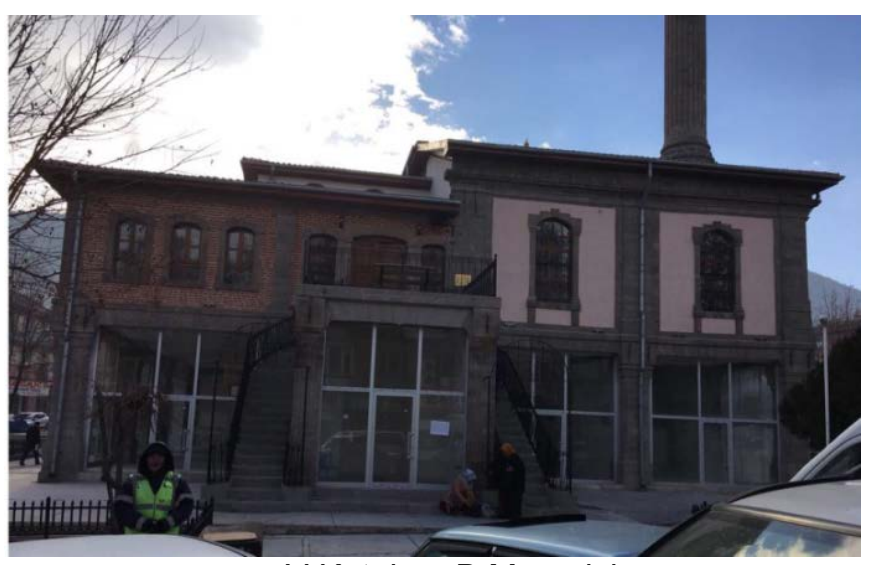

a- V.Kütahya B.M. arşivi

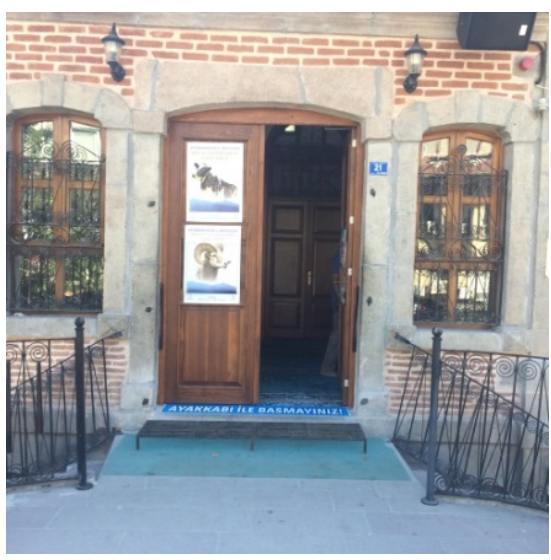

b- Yazarın arşivi, 2019

Resim 7: Yapının giriş (kuzey) cephesinde bulunan çift kollu merdivenler ve ana giriş kapısı.

Ana giriş kapısı $\sim 380$ × $515 \mathrm{~cm}$ ebadında giriş holüne açılır. Holün güneyindeki çift kanat ahşap kapı medreseye, batısındaki kapı son cemaat mekanına açılır. Dikdörtgen planlı $(-1057 \times 590 \mathrm{~cm})$ son cemaat mekanının tavanı ahşap kaplamalı, çatısı tek eğimli ahşap asma çatıdır. Son cemaat mekanının kuzeydoğu köşesine yerleştirilmiş ahşap merdivenle kadınlar mahfiline çıkılır (Resim 8). Son cemaat mekanın güneybatı köşesine minare yapılmıştır. Minarenin ahşap kapısının etrafında kesme taş söve vardır (Resim 9). Söveler dikine dikdörtgen kaide şeklinde başlatılmış, kemere geçişte dışa taşkın formda bir başlık ve kemerde bir tepelik oluşturulmuştur. Söveler ile aynı malzemeden yapılan taş eşik vasıtasıyla minare merdivenine ulaşılır. 


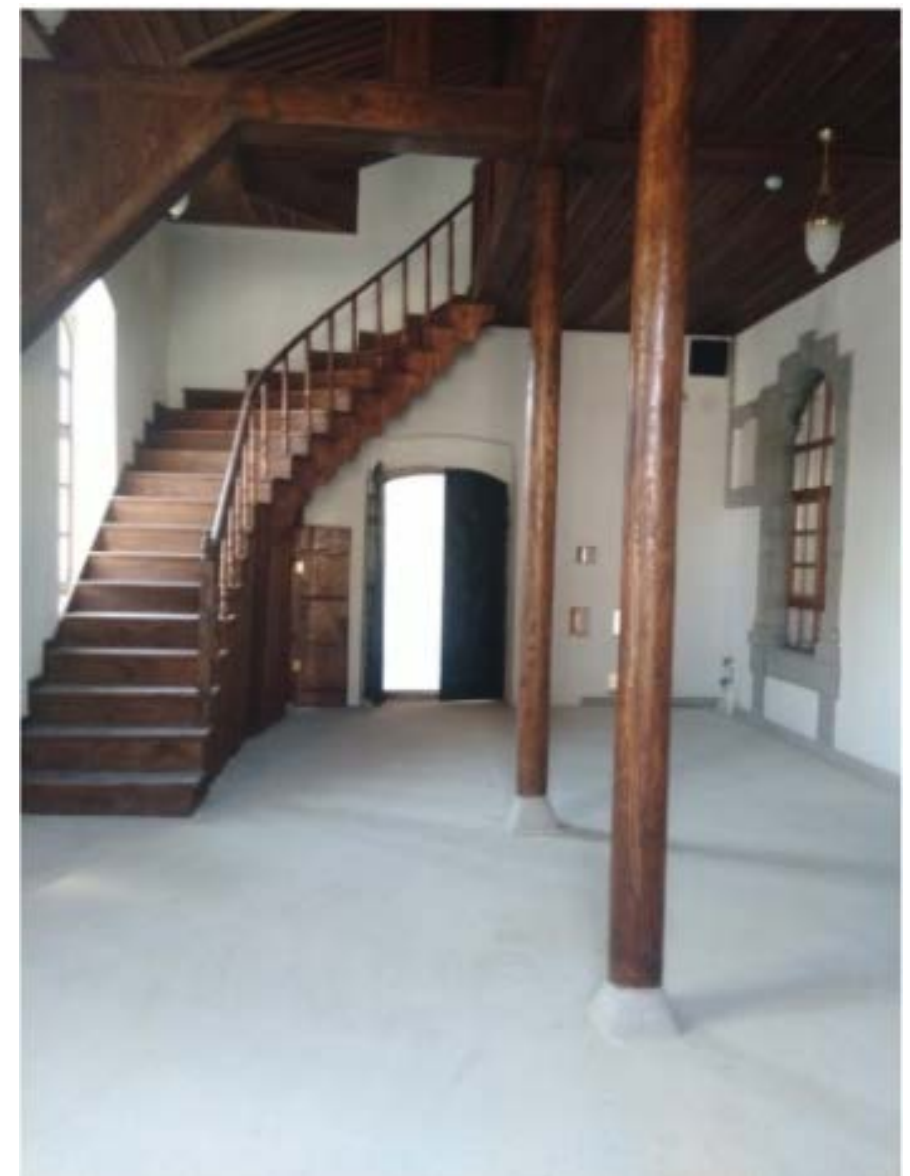

Resim 8: Son cemaat mekanı kadınlar mahfiline çıkan ahşap merdiven (V.Kütahya B.M. arşivi).

Son cemaat mekanı güney duvarında, harime açılan basık kemerli dikdörtgen çerçeve içine yerleştirilen çift kanat ahşap kapı ve kapının iki yanında, kesme taş söveli $(20 \mathrm{~cm})$ birer pencere bulunmaktadır (Resim 10). Söve kilit taşlarına akant süsleme, denizliklere "S" kıvrımlar yapılmıştır.
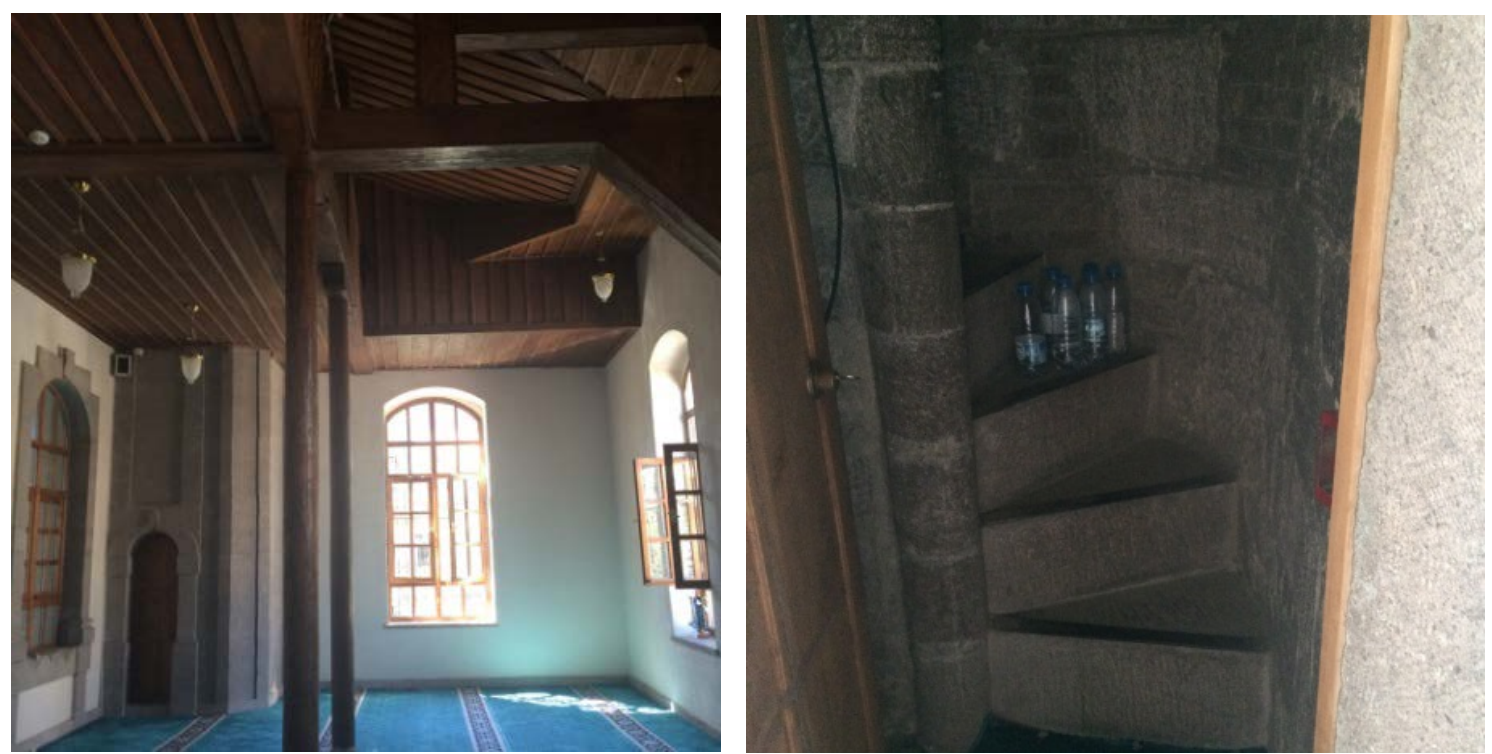

Resim 9: Son cemaat mekanı güneybatı köşesinde yer alan minare ve taş merdiveni (Yazarın arşivi, 2019). 


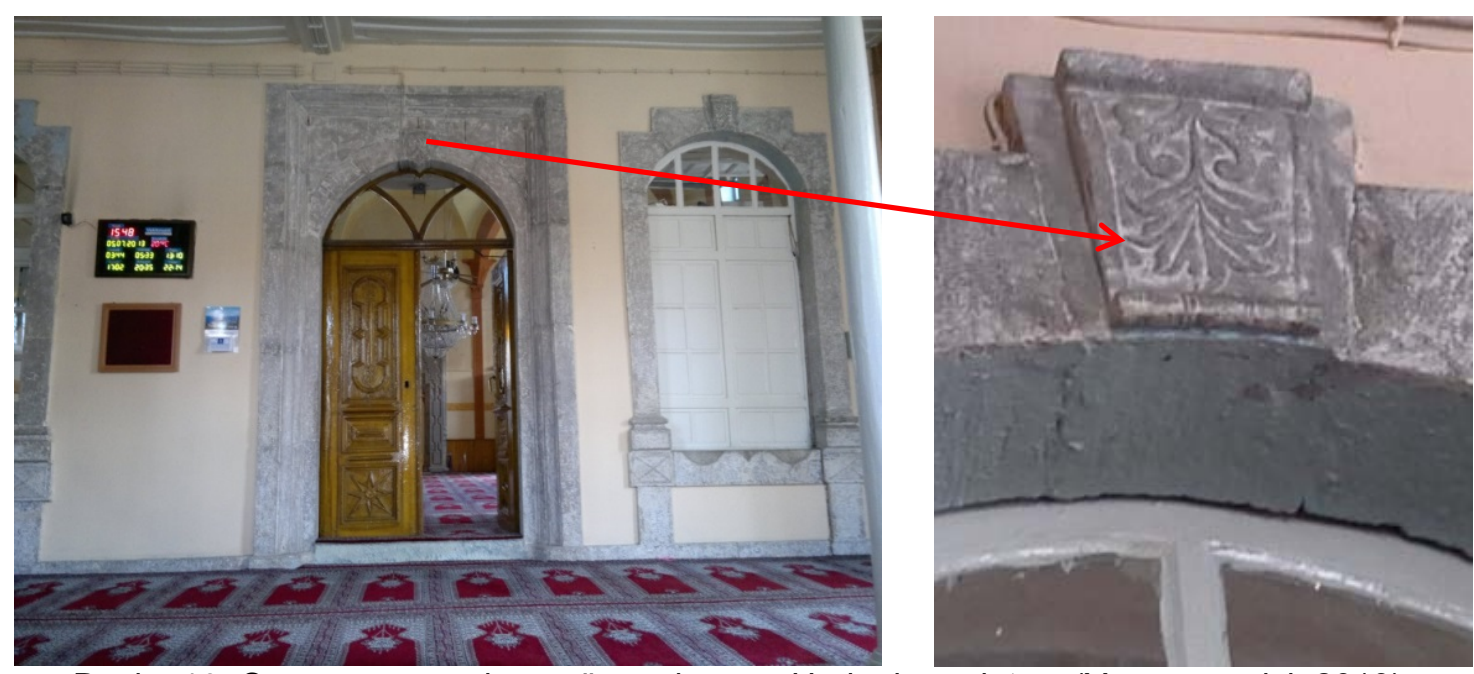

Resim 10: Son cemaat mekanı güney duvarı - Harim kapı detayı (Yazarın arşivi, 2013).

Dikdörtgen planlı harimin içten içe taban ölçüleri $\sim 1050 \times 1130 \mathrm{~cm}$. tavan yüksekliği tekne tavan altına kadar $660 \mathrm{~cm}$, toplam alanı ise kadınlar mahfili dahil $\sim 230 \mathrm{~m}^{2}$ dir. Harimin medreseye bitişik doğu duvarı sağırdır. 2015-2017 yıllarında yapılan restorasyon çalışmaları sırasında bu duvarda tuğla bir kemer ortaya çıkarılmış, kemerin altındaki duvarda nişlerin varlığı tespit edilmiştir. Nişlerin içinin sonradan doldurulduğu anlaşılmıştır (Resim 11). Harimde geniş pencere boşlukları tasarlanarak iç mekan son derece aydınlık kılınmıştır. Kıble duvarının merkezinde taş mihrap, mihrabın iki yanında ahşap minber ve vaaz kürsüsü bulunur. Yarım daire planlı mihrap nişi dışarıya taşırılmamış, kalın beden duvarının içine gömülü olarak yapılmıştır. Mihraptaki ana süslemeler; kesme taştan geniş silmeler ile akant yaprakları ve "S-C" kıvrımlarının farklı formlardaki tipleri ile hareketlendirilmiş alınlıktır. Silme taşlarının üzerine geometrik çizgisel motifler yapılmıştır (Resim 12). Silme taşlarındaki yağlı boya kalıntıları 2017'de tamamlanan restorasyon çalışmalarında temizlenmiştir. Mihrap nişi iç yüzeyi geç döneme özgü alçıdan sıvalıdır Güneybatı köşede yer alan ahşap minber ve güneydoğuda yer alan ahşap vaaz kürsü genel olarak sade olup, geometrik şekiller ve silmelerle hareketlendirilmişlerdir.

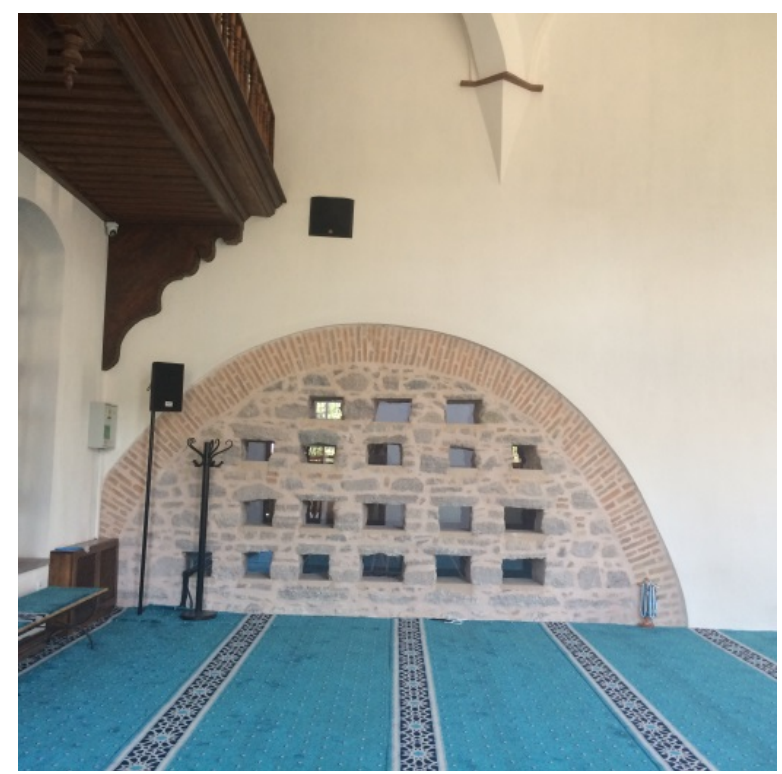

Resim 11: Harim ve medrese ortak duvarındaki kemer detayı (Yazarın arşivi, 2019). 

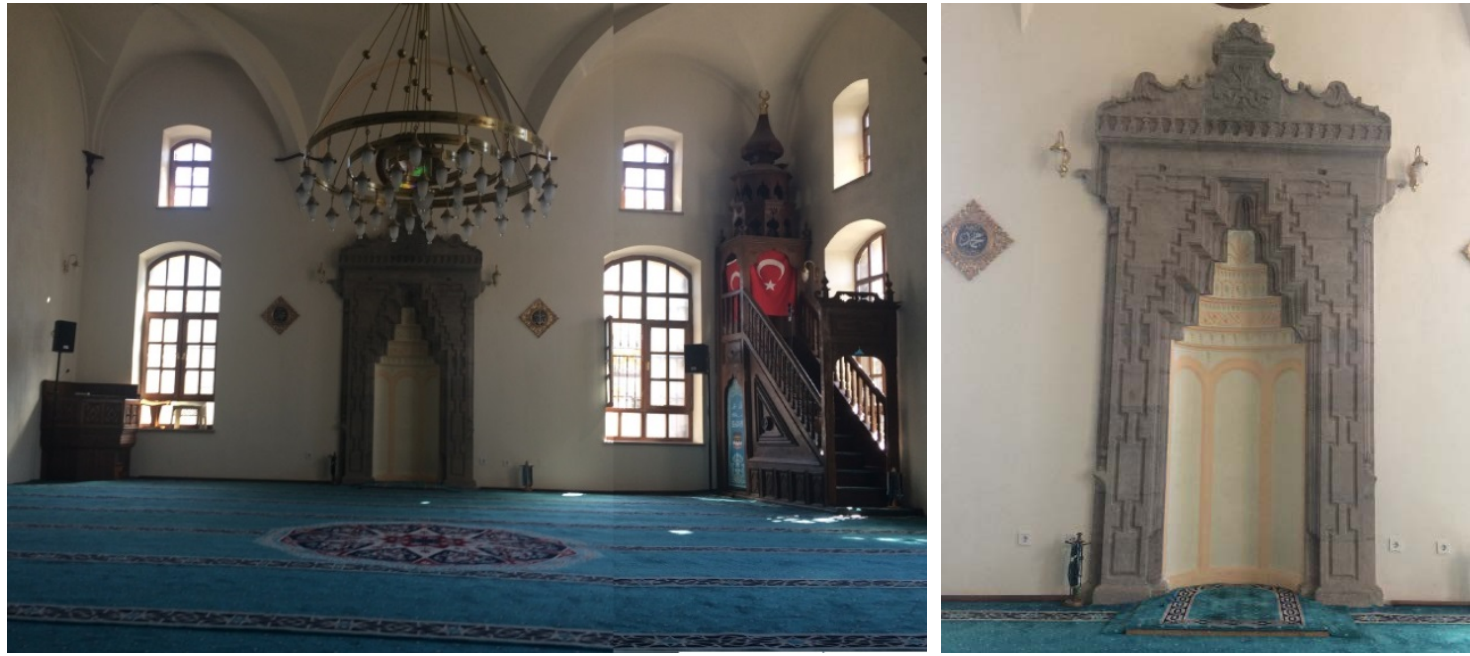

Resim 12: Kıble duvarından genel bir görünüş ve mihrap detayı (Yazarın arşivi, 2019).

Kadınlar mahfilinin bulunduğu kuzey duvarı hariç, harimin duvarlarından tavana geçişte bağdadi geçiş öğeleri kullanılmıştır. Bunlar strüktürel olmayan sütun başlığı, kemer ve pandantiflerdir. Kemer ve pandantifler tekne tavan ile birleşmektedir. Tekne tavanda, ortada stilize edilmiş sekiz uçlu yıldız, dallar ve yapraklardan oluşan süsleme bulunur. Bu süsleme, Geç Dönem Osmanlı camilerinde farklı sayılardaki kollardan oluşan yıldız kompozisyonları süsleme anlayışının yorumlanması olarak düşünülebilir. $140 \mathrm{~cm}$ derinliğindeki tekne tavanın yanal yüzleri dış ve iç bükey biçiminde üç kuşakla, tavanla birleştiği yerde ise diş sırası ile dolaşılmıştır (Resim 13). İç mekanda yapılan bu süslemeler, dönemin mimari özelliklerinin yerel ustalar tarafından yorumlanmış sade uygulamasıdır.

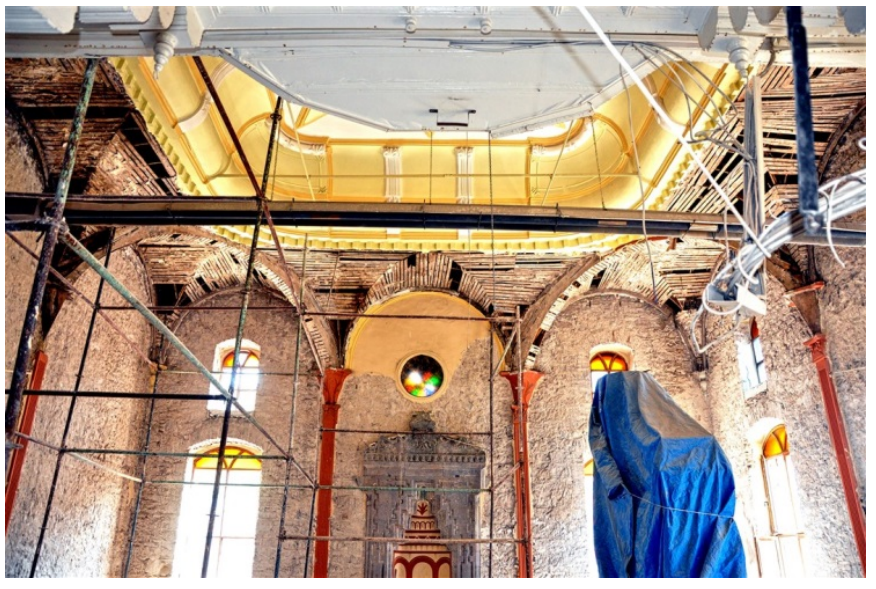

a- URL3

Resim 13: Harim duvarlarından tavana geçişte kullanılan bağdadi geçiş öğeleri ve tekne tavan

\subsubsection{Medrese Bölümü} süslemesi.

Cami bölümünün doğusuna bitişik yapılan medrese, cami gibi dikkat çekici mimari özelliklere sahiptir. Medrese ve zaviyelerin kapatılmasına (1924) kadar medrese fonksiyonunu sürdüren bu bölüm, 1970-1980 yılları arasında müftülük binası olarak kullanılmıştır (Topbaş vd., 2007, s.218). Günümüzde ise eğitim, seminer gibi faaliyetler için kullanılmaktadır.

Medresenin (bkz. Resim 2) orta sofası, fener çatısı ve ahşap süslemeleriyle ilgi çekici mekandır. Odalarla çevrili orta salonun aydınlatılması amacıyla fener çatı 
tasarlanmıştır. Fenerin doğu bölümüne beşik kemerli üç adet, kuzey ve güney bölümlerine ise, ikişer pencere açılmıştır. İç mekanda bu pencerelerin etrafına ahşaplarla enli pervazlar yapılmıştır. Pervazların düşey elemanları, sütun ve sütun başlığı görünümünde detaylandırılmış olup üzerine düşey yivler açılmıştır (Resim 14 A). Orta sofa, dikdörtgen planlı $(1030 \times 680 \mathrm{~cm})$ kat yüksekliği $620 \mathrm{~cm}$ 'dir. Sofa girişinde doğu-batı doğrultuda dikdörtgen bir ön mekân $(140 \times 515 \mathrm{~cm})$ bulunur. Ön mekana giriş holünden beşik kemerli çift kanat ahşap kapıdan girilir. Kapının iki yanında neogotik tarzda sivri kemerli iki adet, ahşap doğramalı pencereler yapılmıştır (Resim 14B).

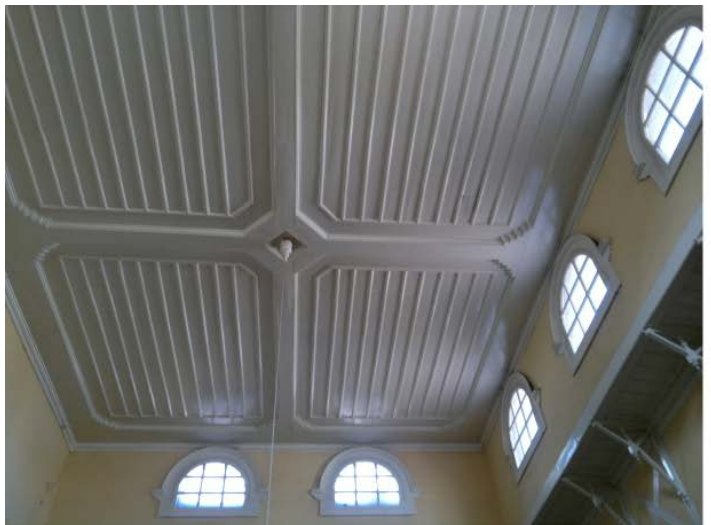

a- Yazarın arşivi, 2019

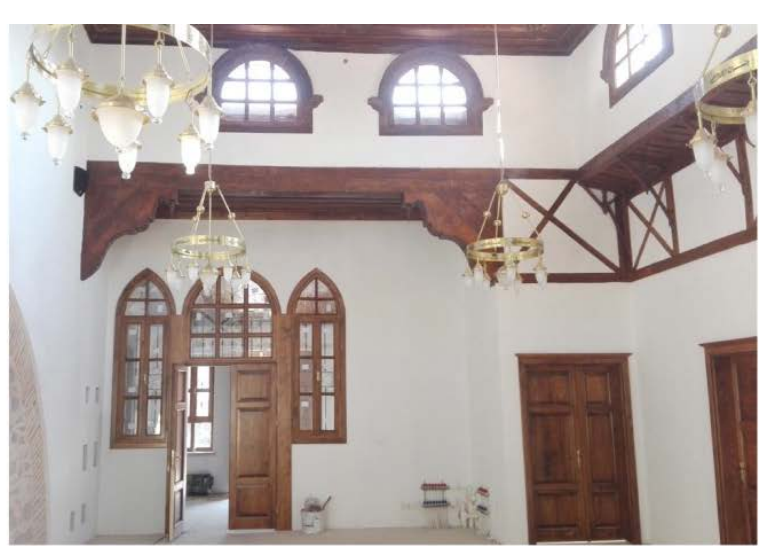

b- V.Kütahya B.M. arşivi

Resim 14: Geç Dönem Osmanlı Mimari özelliklerini taşıyan Medresenin sofa mekanı.

Sofanın doğu ve güney duvarı üzerinde çatı fenerinin başladığı yükseklikte $(\sim 400 \mathrm{~cm})$ duvara hareket kazandıran ahşap çıkma bulunur. Çıkmayı destekleyen ahşap payandalara dekoratif sarkıtlar yapılmıştır. Sofanın tavanı, dört eşit parçaya bölen ve göbeği çerçeveleyen levhalardan oluşmuş düz ahşapla kaplıdır. Sofayı, tavan yükseklileri $\sim 320 \mathrm{~cm}$ olan bir adet dershane ve 6 oda çevrelemektedir. Odaların tavanları düz ahşap kaplama ortada geometrik desenli göbek bulunur. Her odanın içersinde kesme taş ocak bulunmaktadır (Resim 15). Oda duvarlarında her hangi bir süsleme olmayıp kireç esaslı sıva üzeri boyalıdır. Medrese bölümünün döşemesi horasan tesviyesi üzeri halı kaplamadır.
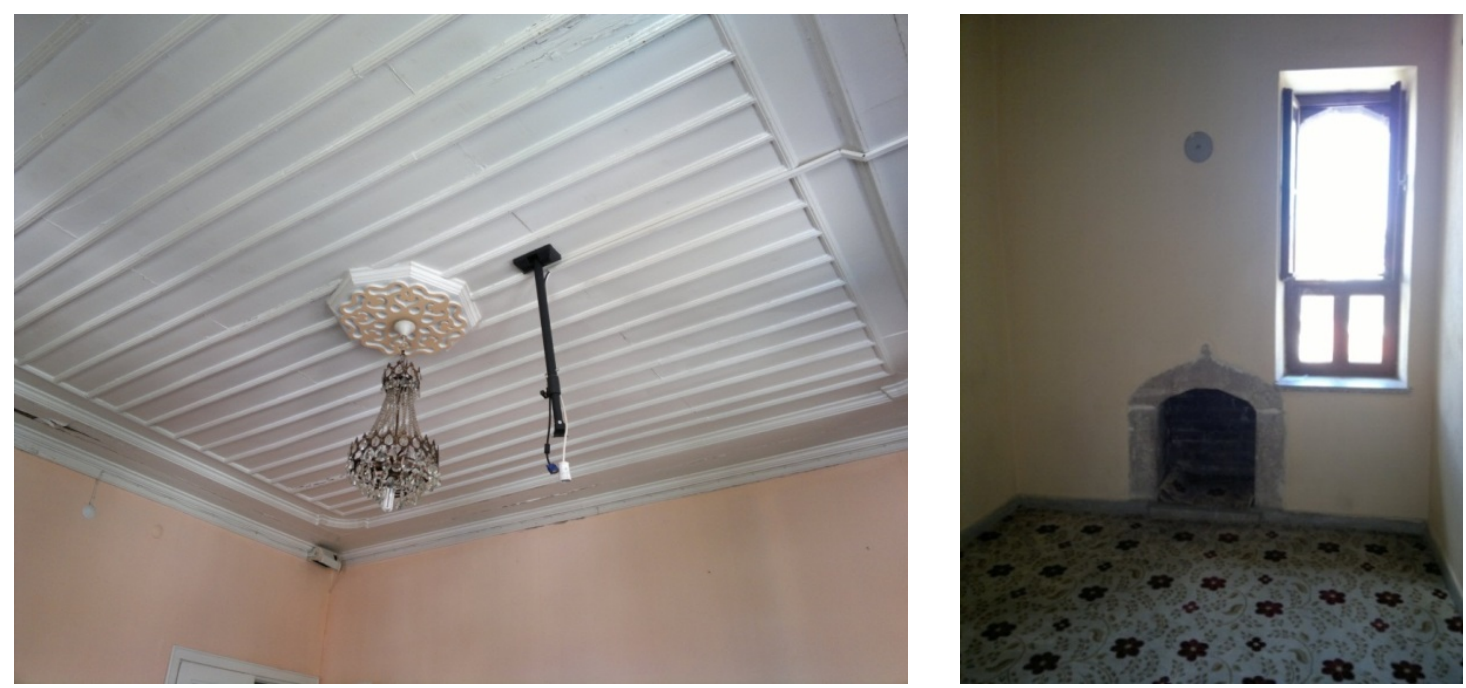

Resim 15: Medrese odalarından ahşap tavan ve ocak detayı (Yazarın arşivi, 2013). 


\subsection{Cephe Özellikleri}

Yapının cephelerinde Geç Dönem Osmanlı mimarisinin özellikleri ve yerel mimarlığın izleri görülmektedir. Genel olarak yapı, birbirine bitişik kütleler olarak algılanmakta ve üç kademeli bir görünüm yansıtmaktadır. İlk kademe zemin kat; yüzeyine taraklama yapılmış taş blokların üst üste dizilmesiyle oluşturulmuş taş ayakların vurgulandığı kısımdır. İkinci kademe, binaya hakim konumdaki topuz çatılı cami bölümü; beden duvarları medrese ve son cemaat bölümlerine göre daha yüksek olup taş işçiliğinin öne çıktığı bölümdür. Üçüncü kademe ise, medrese, son cemaat mekanlarının ve minarenin yer aldığı kısımdır.

Yoncaaltı Cami ve Medresesi, cephe tasarımı ile barok ve eklektik üslupları çağrıştırmaktadır. Üçlü pencere düzenleri, silme kuşakları, kompozit başlıklı ve profilli sütunlar ile plasterler, silme kuşakları, topuz çatının saçakları ve yuvarlak kemerli mihrap üstü penceresi cepheleri hareketlendiren unsurlardır. Yapının güney ve batı cephesinin tamamı düzgün kesme taş ile kaplı olup, dönemin unsurları yerel ustalarca biçimlendirilmiştir.

Cami bölümünü çevreleyen kalın beden duvarlarının pencere açıklıklarıyla ve çeşitli süslemelerle hafifletilmesi kütlesel bakımdan iç ve dış arasındaki uyumu sağlamıştır. Saçak altında duvar yüzeyinden taşırılmış düz, dış ve iç bükey profilli silme kuşağı tüm cepheleri çevreler. Batı ve güney cephelerinin alt ve üst sıra pencere dizileri arasındaki yatay silme, cephede iki katlı izlenimi yaratmıştır. Bu silme son cemaat yeri saçak altındaki silme ile birleşmektedir. $+4.30 \mathrm{~m}$. kotunda $\sim 120 \times 300 \mathrm{~cm}$ ölçülerindeki alt pencere ve $+7.90 \mathrm{~m}$. kotunda $\sim 60 \times 135 \mathrm{~cm}$ üst pencere açıklıklarının kemer ve silmeleri oldukça dikkat çekicidir. Geç Dönem Osmanlı camilerinin süslemelerinde, sık karşılaşılan bezeme öğesi akant yaprağı pencere kemerindeki kilit taşında yer almaktadır. Güney cephesinde mihrap eksenini merkez alan simetriyle üst kısımda üçlü pencere, alt kısımda ise iki pencere açıklığı bulunmaktadır. (Resim 16). Mihrap nişi dışarıya taşırılmamış, kesme taş söve, kemer ve yuvarlak kemerli üst pencere ile vurgulanmıştır. Pencere açıklıklarında taş denizlik uygulaması ile bütünlük sağlanmıştır. Barok süsleme kompozisyonlarından iki adet sırt sırta vermiş "S kıvrımı" denizliklerin ortasına yerleştirilmiştir( bkz. Resim 16). Tüm pencereler ahşap doğramalı ve demir ferforje parmaklıklıdır.
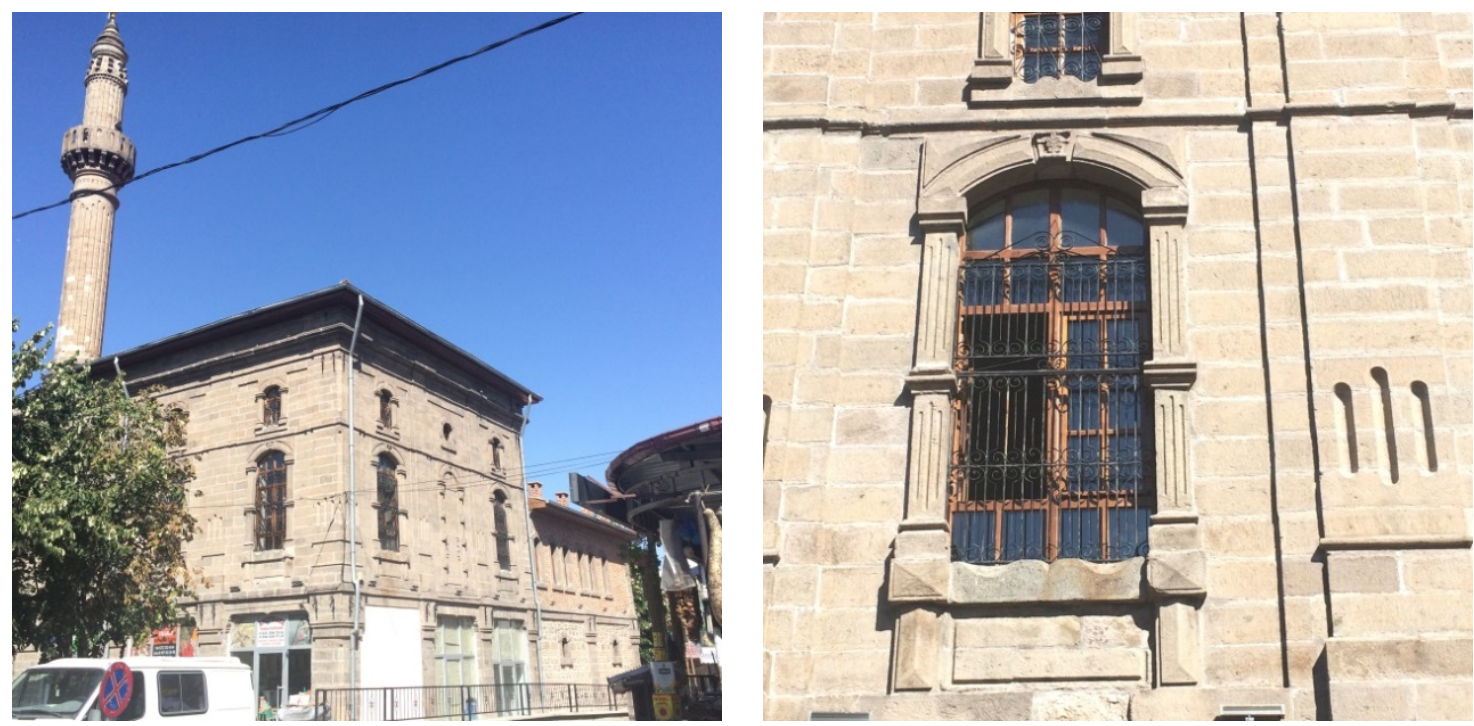

Resim 16: Yoncaaltı Cami güneybatı görünüşü ve pencere detayı (Yazarın arşivi, 2019). 
Medrese bölümü güney cephesi, camiye kıyasla daha sade tasarlanmıştır. Duvarları düz tuğla örgülüdür. Ahşap saçak altında taş silmeler bulunur. Silme, harim cephesinde olduğu gibi duvar yüzeyinden taşırılmış düz, dış ve iç bükey profillidir. Medrese pencerelerinin genişliği $75 \mathrm{~cm}$, aralarındaki boşluklar $60 \mathrm{~cm}$ ve $100 \mathrm{~cm}$ olup taş söveli basık kemerlidir. Cami cephesindeki taş yüzeyler ile medrese bölümünün sıvasız tuğla yüzeylerin yarattığı kontrast bu cephede görülebilmektedir (Resim 17).

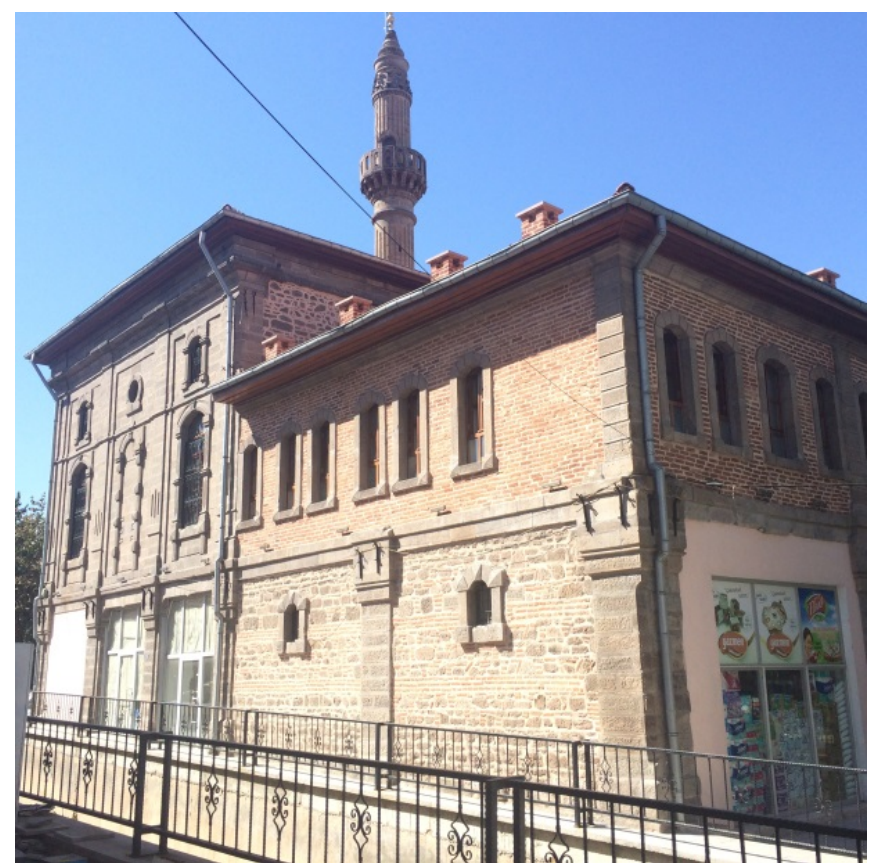

Resim 17: Güneydoğu köşesinden bakış; Cami ve Medrese bölümü (Yazarın arşivi, 2019).

Yapının doğu cephesi, tamamen Medrese bölümünün ön planda olduğu kısımdır. Güney cephesindeki medrese bölümünün özellikleri, doğu cephesinde de devam etmiştir. Farklı olarak, zemin kat taş ayakların hizasına yapılan kesme taş plasterlerdir (Resim 18).
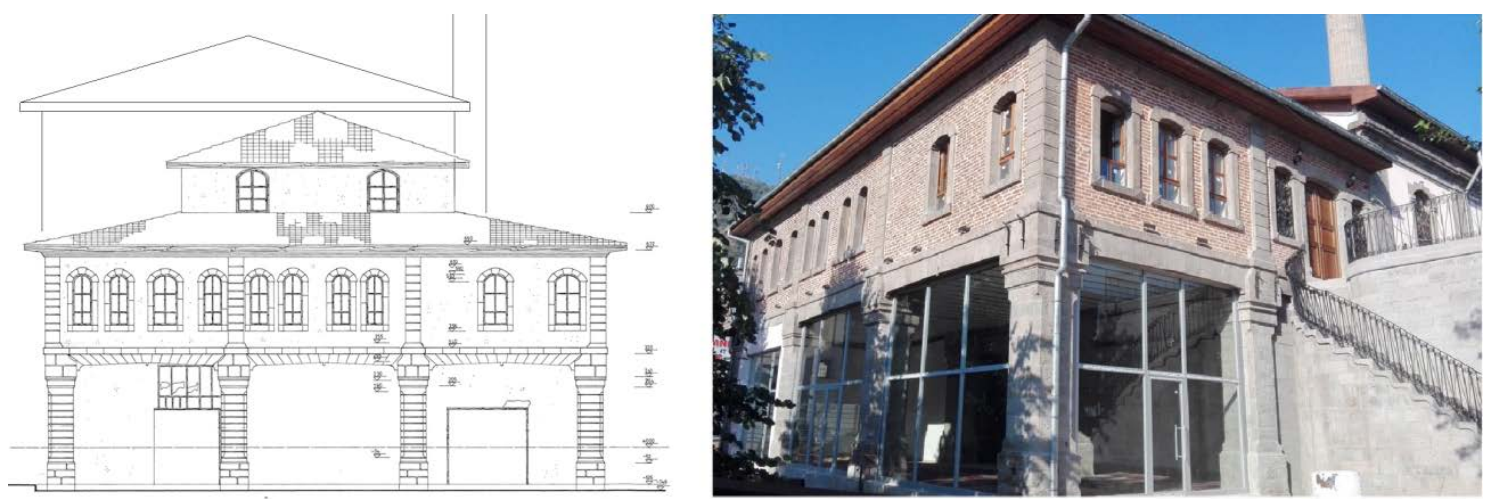

Resim 18: a- Doğu cephesi Rölevesi (VGMA, 2013), b- Kuzeydoğu köşesinden Medrese bölümü ve alt kattaki dükkanlardan bir görünüş (V.Kütahya B.M. arşivi, 2017).

Yoncaaltı Cami ve Medresesi'nin yangından sonra yeniden inşaatını gösteren 1910 tarihli fotoğraf değerlendirildiğinde, medrese bölümünü duvar örgüsündeki tuğlaların sıvasız olduğu ve saçak altında süslemeler yapıldığını söylemek mümkündür (Resim 19). Bu süslemeler sonraki yıllarda yapılan onarımlarda cephenin sıvanması sırasında kapatılmıştır. 2015-2017 yıllarında yapılan restorasyon çalışmalarında sıvalar kaldırılmış, ancak saçak altı süslemeleri bulunamamıştır. 


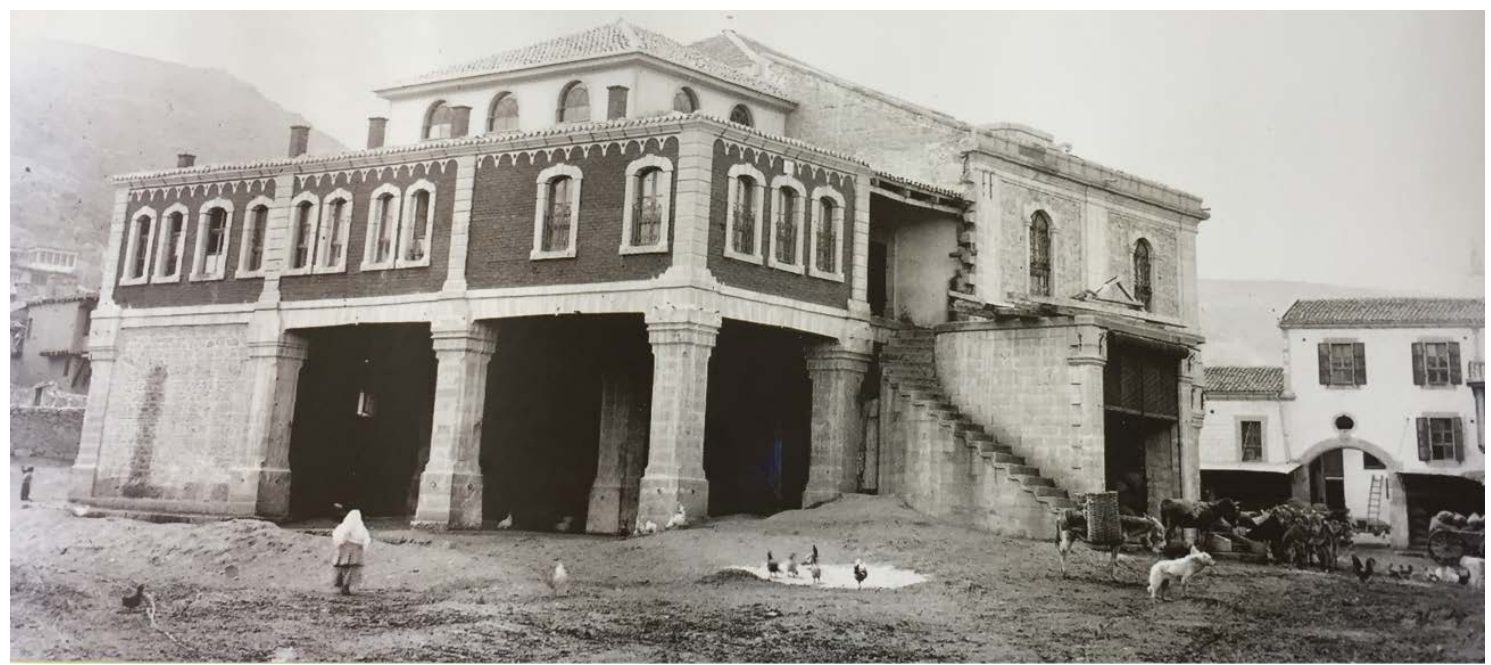

Resim 19: Yoncaaltı Cami'nin yangından sonra yeniden inşaatı, 1910, Foto Şeref arşivi,

( Özpunar, 2014, s. 56).

Yapının kuzey cephesinde, medrese bölümüne ait üç adet pencere, ana giriş kapısı ve son cemaat mahalline ait iki adet pencere bulunmaktadır. Medrese ve giriş bölümü pencereleri basık kemerli, $20 \mathrm{~cm}$ genişliğindeki taş sövelerle çerçevelenmiştir. Son cemaat bölümü pencereleri ise daha basık kemerli olup, ebat ve taş söve işlemeleri farklıdır. Bu durum, mekan farklıığının cepheye yansıtııması olarak düşünülebilir. Giriş ve medrese bölümüne ait duvarlarda harman tuğlası kullanılmış olup üzeri sıvasızdır. Son cemaat bölümünün duvarları ise sıvalıdır. Köşelerde kesme taştan plasterler yapılmıştır. Plaster kaplama taşları çerçeveli olup yüzeyi taraklanmıştır.

\section{Yapım Sistemi ve Malzeme Kullanımı}

Binanın strüktürü, taş temel üzerine taş ayaklar, kagir taşıyıcı duvarlar üzerinde, o dönemde yeni kullanılmaya başlanan putrelli volta döşemeler ve ahşap karkasın kullanıldığı karma sistem ile oluşturulmuştur.

Zemin kattın taşıyıcı sistemini, kesme taştan yapılmış ayaklar $(85 \times 85 \mathrm{~cm})$ ve bazı bölümlerde $50 \mathrm{~cm}$ kalınlığındaki moloz taş duvarlardan tasarlanmıştır. Ayaklar arası açıklık doğu batı doğrultusunda $\sim 565 \mathrm{~cm}$ kuzey-güney doğrultusunda $\sim 605 \mathrm{~cm}$ 'dir. Tavan döşemesi, ayaklar ve moloz duvarlar tarafından taşınan volta döşemedir. Kuzeygüney aksında, ayaklar üzerindeki çift I putreller ana kiriş görevindedir. Ana kirişlerin üzerine $\sim 50-55 \mathrm{~cm}$ aralıklarla tali I kirişler yerleştirilmiştir. Vakıflar Genel müdürlüğü arşiv taramasında bulunan tarihi bilinmeyen siyah beyaz bir fotoğraftan (Resim 20A) ayaklar ve döşeme kirişlerinin detayı görülmektedir. Tali kirişlerin araları, dikine dolu tuğla dolgu üzeri sıvalıdır (Resim 20B). 2015-2017 yılları arasında yapılan restorasyon çalışmasında sadece merdiven altındaki dükkanda volta döşeme sıvanması yapılmamış, böylece örgü biçimi ve malzemesi sergilenmiştir. Güney cephesinin bazı bölümlerinde moloz taş ve harman tuğla duvar örgü görülür. 


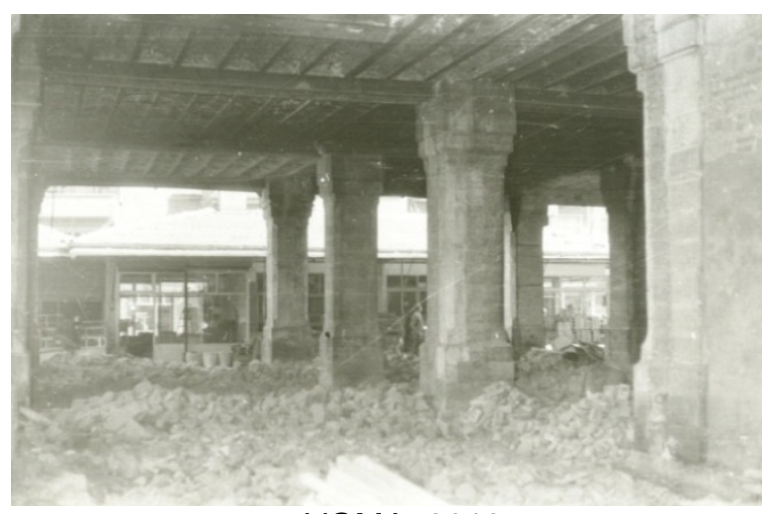

a- VGMA, 2013

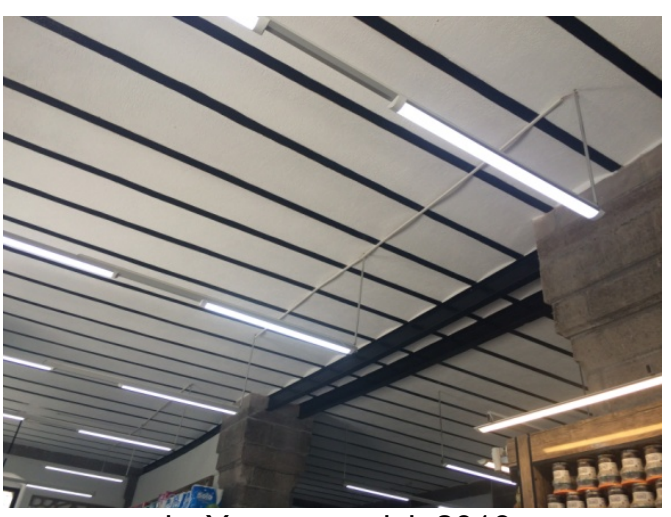

b- Yazarın arşivi, 2019

Resim 20: Dükkanların bulunduğu zemin katta kesme taştan yapılmış ayaklar ve putrel döşeme kirişleri;).

Caminin 50-60 cm kalınlığındaki dış duvarları moloz taş örgü üzeri Trakit $^{1}$ taşı kaplamadır (Resim 21). Yapının genelinde kullanılan taşlar, Afyon yöresine özgü, siyaha yakın gri ve açık pembe renkte trakit ve andezit taşıdır ${ }^{2}$. Medrese kısmının dış duvarları harman tuğlası ile örülmüştür. Dış cephede yanal yüklere karşı dayanımı artırmak amacıyla, zemin kat cephesindeki tüm ayaklarda ve cami bölümünün saçak altı seviyesindeki köşelerinde dökme demir kılıçlar kullanılmıştır (Resim 22). Harim bölümünün üzeri topuz çatı olup alaturka kiremit kaplamadır.

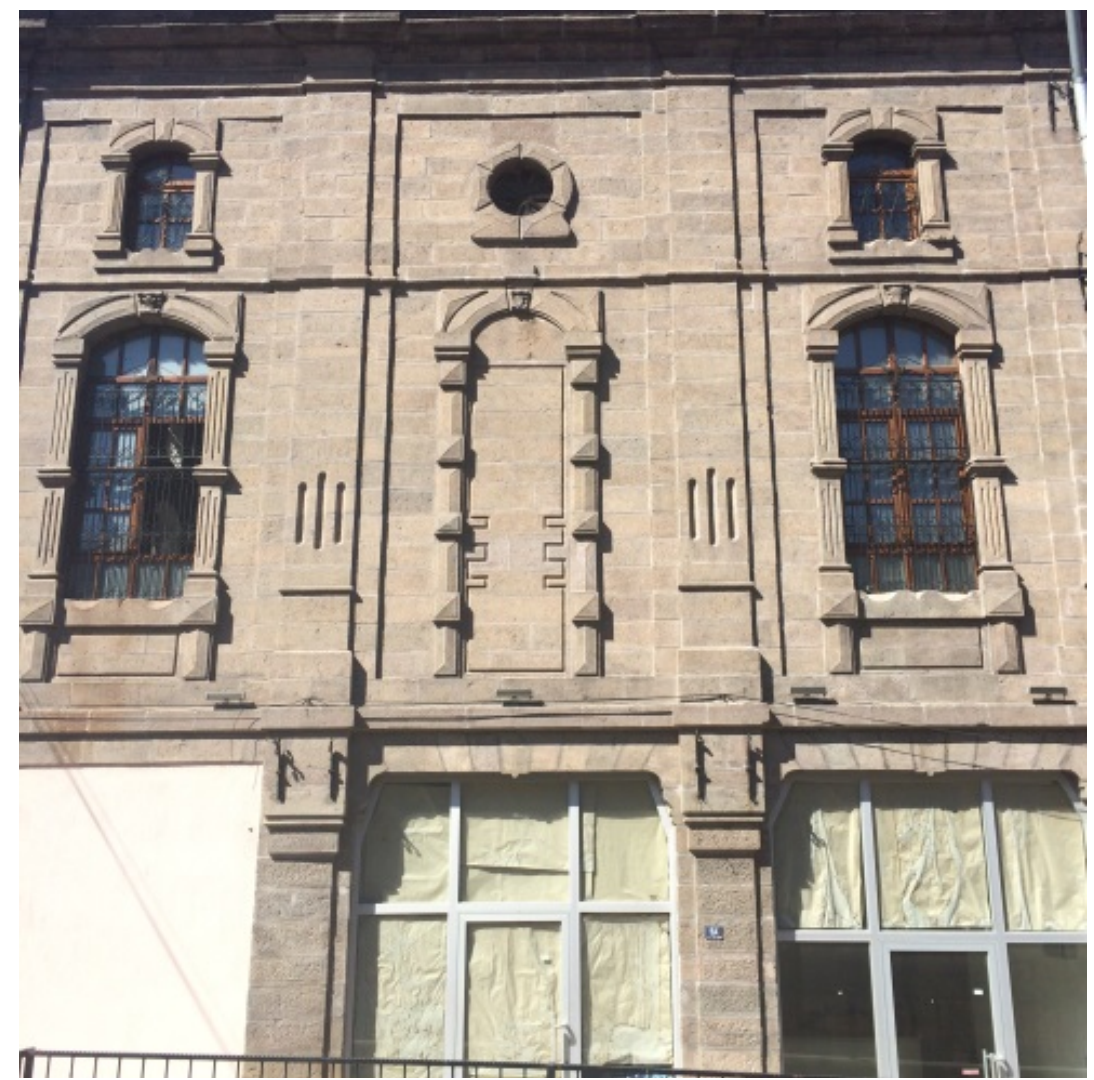

Resim 21: Cami bölümü güney cephe mihrap nişi detayı; moloz örgü üzeri kesme taş kaplama (Yazarın arşivi, 2013).

\footnotetext{
${ }^{2}$ Yörede Afyon volkanitleri olarak bilinen bu taşlar jeolojide "Trakiandezitler" olarak adlandırılmaktadır. Trakiandezitler genellikle gül kurusu ağırlıklı bir renk gösterir. Bu renk kayacın içerdiği demir oksit bileşiklerinden ileri gelmektedir. Yapıda kullanılanlarda kırmızımsı, pembe ve gri renk izlenmiştir. Trakiandezitler bileşimindeki açık (kuvars, feldispat) ve koyu renkli (biyotit ve az miktarda hornblend) mineraller nedeniyle benekli bir görünüme sahiptir (Çelik, vd., 2001, s. 29).
} 

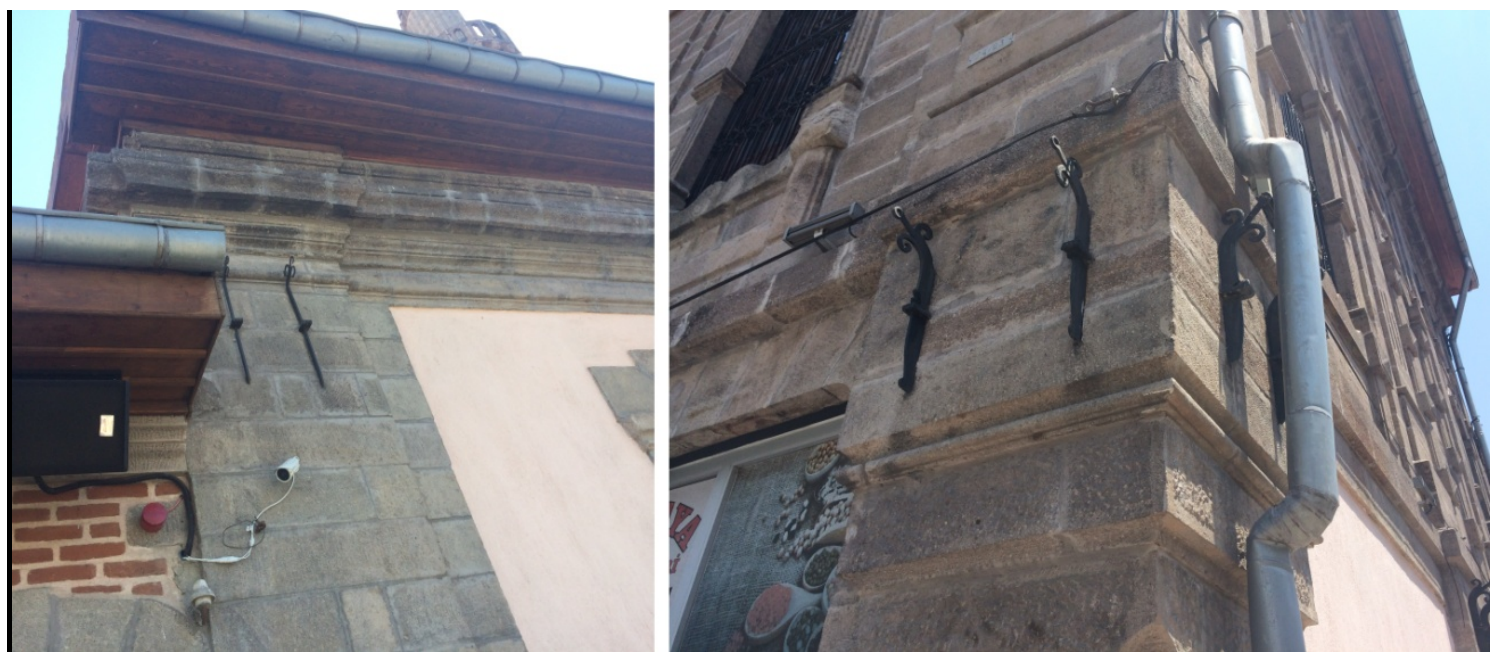

Resim 22: Taşıyıcı sistemde kullanılan demir kılıçlar (Yazarın arşivi, 2019).

Medrese bölümünün iç duvarlar kalınlığı yaklaşık $15 \mathrm{~cm}$ olup ahşap karkas sistem ile yapılmıştır. İç mekân incelemesinde yapının tadilat öncesi hâlini gösteren tarihi bilinmeyen siyah beyaz bir fotoğrafta (Resim 23) duvarların ahşap karkas sistemi ve malzemeleri ayırt edilebilmektedir. Ahşap dikme ve diyagonaller arası harman tuğla dolguludur.

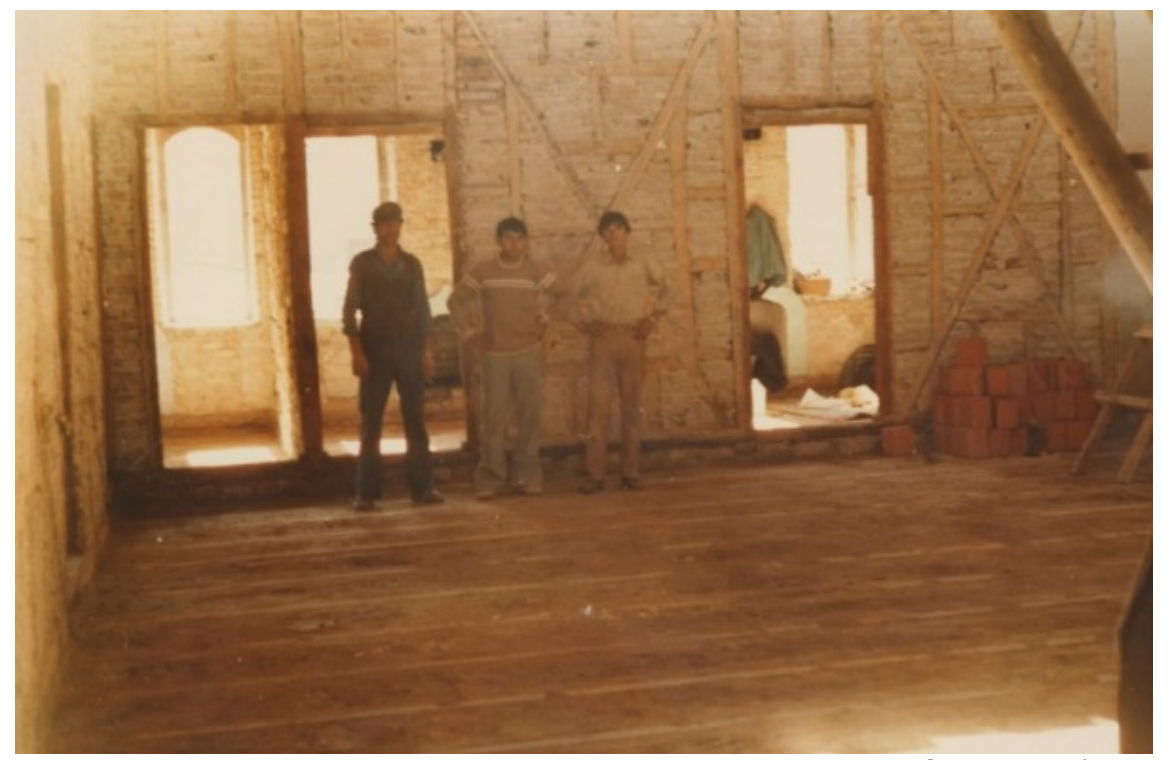

Resim 23: Medrese bölümü ahşap karkas iç duvarlar (VGMA,2013).

Yoncaaltı Cami'nin son cemaat mekanı ve harim arasına yapılan kadınlar mahfili iki kademeli tasarlanmış olup ahşap döşemelidir. Geç Dönem Osmanlı camilerindeki kadınlar ve müezzin mahfilleri genel olarak ahşap malzemeden oluşan elemanlardan meydana gelir. Son cemaat bölümündeki mahfilin döşemesi doğu-batı duvarı yönünde yerleştirilen ahşap ana kiriş ile taşınmaktadır. Bu kiriş, daire kesitli iki ahşap dikme ile desteklenmiştir. Harim kısmının üzerindeki mahfilin konsolu, dış duvarlar ve ortadaki iki adet ahşap eli böğründe ile taşınmaktadır. Özenli yapılmış mahfilde ahşap malzeme öne çıkmıştır. Son cemaat bölümü üzerine gelen kadınlar mahfili bölümünün tavanı çatı eğiminde ve tavan tahtası kaplamalıdır (Resim 24). Mahfil korkuluğu yarım daire formlu çıkıntıyla dışarıya taşırılmıştır. 


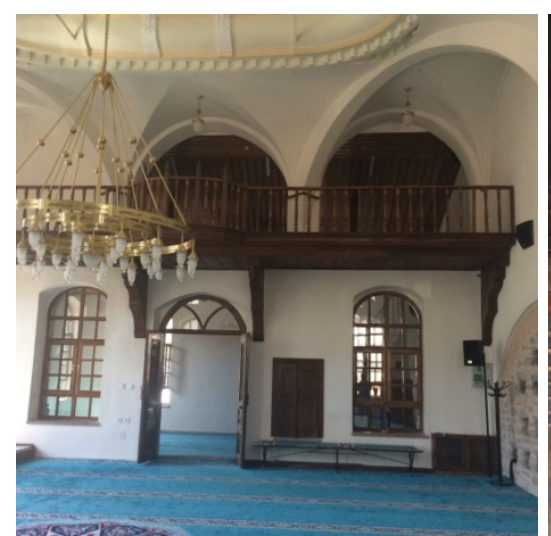

Resim 24: Harim kuzeyi genel görü

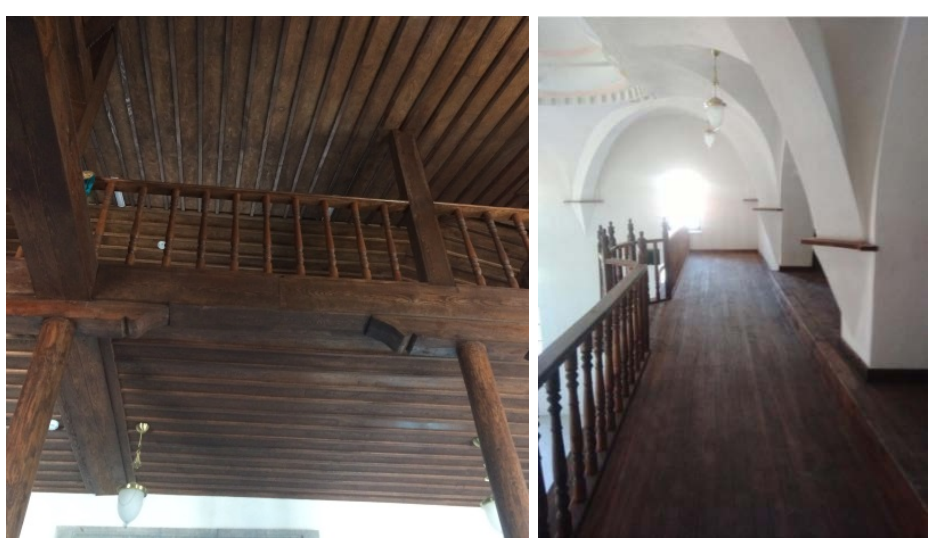

B.M. arşivi, 2017).

Minare, son cemaat yerinin güneybatı köşesinde harim ile birleştiği noktada yükselmektedir. Minare, dış cepheden yapı duvarları ile bir bütünlük göstermektedir. Minare, kare planlı $(215 \times 215 \mathrm{~cm})$ kaidenin üzerinde silindirik gövdeli ve tek şerefeli olup kesme taştan yapılmıştır. Kaide beden duvarı boyunca yükselmekte olup, saçak seviyesinde taş bilezik ile gövdeye geçilmektedir. Yüksekliği $-30.70 \mathrm{~cm}$ olan minarenin, silindirik taş gövdesi (iç çap $\sim 170 \mathrm{~cm}$.) üzerine dikine yivler oyulmuştur. Gövdeden şerefeye geçişte taş bilezik yapılmıştır. Şerefe taş payandalarla genişletilmiştir. Şerefe korkuluğu, ince taş plakaların yan yana getirilmesiyle yapılmıştır. Gövdeye göre daha küçük çaptaki petek, dikine yivlidir. Petek üzerindeki külahın başlangıcında dişler ve üzerinde bitkisel motifli bilezikler yer alır. Son yapılan restorasyonda minarenin gövdesinde ve peteğinde bulunan niteliğini yitirmiş taşların yerine aynı türden taşlar ile kaplama yapılmıştır, PVC şerefe kapısı sökülerek yerine ahşap kapı yapılmış ve alem sökülerek bakım ve onarımı yapılarak yerine takılmıştır.

\section{Değerlendirme ve Sonuç}

Buraya kadar üzerinde durulan değerlendirmeler dikkate alındığında, Yoncaaltı Cami ve Medresesi olarak anılan yapının Geç Dönem Osmanlı mimarisi özelliklerini gösterdiği açıktır. Cami yapısının içinde medresenin yer alması, yarı açık son cemaat yerinin kalkması, taş işçilikleri, süslemeler, sivri kemerler ve kubbenin olmaması gibi özellikler, Geç Dönem Osmanlı cami mimarisini yansıtmaktadır. Yapı, döneminin sosyo-kültürel yapısı ile mimari özelliklerini belgeleyen bir kültür mirası olup, mimarlık tarihi bağlamında iki belirgin eksende önemli anıtlar arasında yer almayı hak etmektedir. İlk inşa edildiği yıllardan itibaren ibadet, eğitim ve ticaret işlevleriyle kent içerisinde önemli bir gereksinimi, dönemin özelliklerini yerel ustaların marifetiyle gerçekleştirildiği bir mekan anlayışı içerisinde yerine getirmektedir. Ancak daha da önemlisi, temelde farklı işleve sahip iki mimari yapının aynı kütle içerisinde özgün bir yorum katılarak, başarılı bir şekilde inşa edilmiş olmasıdır.

Fevkani tasarlanan yapı strüktürü, taş temel üzerine taş ayaklar, kâgir taşıyıcı duvarlar üzerinde, o dönemde yeni kullanılmaya başlanan putrelli volta döşemeler ve ahşap karkasın kullanıldığı geleneksel sistemler ile oluşturulmuştur. Yapıda malzeme olarak; harman tuğlası, putrel, ahşap ve Afyonkarahisar çevresinden çıkarılan volkanik kökenli taşlar (trakit, andezit, vb.) kullanılmıştır. Ahşap, taş ve tuğla hem yapısal amaçla, hem de süsleme amacıyla değerlendirilmiştir: Cephe düzlemlerini tanımlayan tamamen süsleme amacıyla yerleştirilmiş kesme taş silme, friz, söve, kemer, plaster kompozisyonları, dönem mimarlık üslubunun yerel mimarlık gelenekleriyle harmanlanarak taşraya uzantısını gösteren önemli örneklerdir. Harim tavanındaki 
kemer, pandantif ve tavan süslemeleri, medrese orta sofasındaki ahşap işçiliği, giriş kapısının iki yanındaki sivri kemerli ahşap doğramalar, dönemin mimari özelliklerinin yerel ustalarca güzel bir yorumudur.

Özetle 'mimarlık tarihi' değeri ile yapı, sadece Afyonkarahisar'ın yerel mimari kültüründe değil, Türk mimarlık tarihinde ender bir örnek olması nedeniyle korunması gereken önemli bir kentsel mimari eser olarak kabul edilmelidir. Yapılan çalışmadan edilen verilerin ileride yapılacak planlama ve düzenleme çalışmalarına katkıda bulunabilir. Çalışma kapsamında yapının, mimari ve yapısal özellikleri incelenmiştir. Daha sonraki çalışmalarda bina, sürdürülebilirlik, yerel mimari, yapısal davranışlar, statik-dinamik özellikler, vb. farklı konulardan araştırılabilir.

Teşekkür: Çalışmada yararlanılan röleve projeleri ve arşiv bilgileri Ankara Vakıflar Genel Müdürlüğü ve Vakıflar Kütahya Bölge Müdürlüğü'nden temin edilmiştir. Yardımlarından dolayı kuruma teşekkür ederim.

\section{Kaynaklar}

Anonim, Anadolu'nun Kilidi Afyon, Afyon Valiliği, Yayın No:21, Afyonkarahisar 2004.

Akar, İ. "Geçmişte Afyonkarahisar'da Pazar Yerleri”, Taşpınar Degisi, 13, 2014, s.5455.

Aslanapa, Oktay, Osmanlı Devri Mimarisi, 2. Baskı, İnkılâp Yayınları, İstanbul 1986.

Çelik, M.Yavuz, ve Kavas, Taner, "Elvanpaşa (Afyon) Trakiandezitlerinin Jeolojisi Ve Yapı Taşı Olarak Kullanılabilirliğinin Araştııılması", Osmangazi Üniversitesi Müh.Mim.Fak.Dergisi, 14(2), 2001, s.24-36.

Karazeybek, M., Polat, Z., ve Ilgar, Y., Afyonkarahisar Vakıf Eserleri, Cilt I, Afyon Kocatepe Üniversitesi Yayını, No. 60, Afyonkarahisar 2005, s..241-247

İlgar, Y. ve Karazeybek, M. Afyonkarahisar'da Cami ve Mescitler. Afyonkarahisar Kütüğü, Cilt I, s.295-341, Afyon Kocatepe Üniversitesi Yayın No: 35, Afyonkarahisar 2001.

Özpınar, Hasan, Bir Zamanlar Afyonkarahisar, Afyonkarahisar Belediyesi Kültür Yayınları No-23, s.56-57, 2014.

Öztank, N. 2013- 2019. Fotoğraf Arşivi.

Polat, Sibel, İzmir'deki Geç Dönem Osmanlı Camileri, Selçuk Üniversitesi Sosyal Bilimler Enstitüsü Yüksek Lisans Tezi, Konya 2011.

Topbaş, A., Üyümez, M., Kaya, F. Tarihi ve Günümüz Afyonkarahisar Camileri, Alimoğlu Grup Kültür Yayınları-1, s.214-218, Afyonkarahisar 2007.

Vakıflar Genel Müdürlüğü Arşivi, Ankara.

Vakıflar Kütahya Bölge Müdürlüğü Arşivi, Kütahya

VGMA-1 Vakıflar Genel Müdürlüğü Arşivi, Defter, nr. 581/1, s. 35, no 35; VGMA, Defter, nr. 2228, s. 24, no 14. 
VGMA-2 Vakıflar Genel Müdürlüğü Arşivi, Defter, nr. 571, vr. 15b/94; nr. 613, s. $82 / 475$.

VGMA-3 Vakıflar Genel Müdürlüğü Arşivi, Defter, nr. 608/2, s. 143, sıra: 121-123.

VGMA-4 Vakıflar Genel Müdürlüğü Arşivi, Defter, nr. 608/2, s. 143, sıra: 121-123.

URL1, https://aku.edu.tr/nadir-kirgiz-kolleksiyonu/ (Erişim tarihi, 20 Mayıs 2020)

URL2, https://www.kentselstrateji.com/wp-content/uploads/V-32 Afyonkarahisar.pdf Afyonkarahisar Kale-Çarşı-Mahalle Turizm ve Kültür Rehberi, 2016, Afyonkarahisar Vizyon Rehberi Çalışması, T.C. Kalkınma Bakanlığı, Afyonkarahisar Valiliği, Zafer Kalkınma Ajansı (Erişim tarihi, 20 Mayıs 2020).

URL3, https://www.akcaylarrestorasyon.com/portfolio/yoncaalti-camii/(Erişim tarihi, 1 Eylül 2017) 